\title{
Article \\ Evaluation of CADI Low Alloyed with Chromium for Camshafts Application
}

\author{
Alejandro Cruz Ramírez ${ }^{1, *(D)}$, Eduardo Colin García ${ }^{1}$, José Federico Chávez Alcalá ${ }^{1}$, Jaime Téllez Ramírez ${ }^{2}$ \\ and Antonio Magaña Hernández ${ }^{2}$
}

1 Instituto Politécnico Nacional-ESIQIE, UPALM, Ciudad de México 07738, Mexico; ecoling1400@alumno.ipn.mx (E.C.G.); jfchavez@ipn.mx (J.F.C.A.)

2 R\&D ARBOMEX S.A de C.V., Calle Norte 7 No. 102, Cd. Industrial, Celaya 38010, Mexico; ingfundi@arbomex.com.mx (J.T.R.); antonio.magana@arbomex.com.mx (A.M.H.)

* Correspondence: alcruzr@ipn.mx; Tel.: +52-55-5729-6000 (ext. 54202)

check for

updates

Citation: Cruz Ramírez, A.; Colin

García, E.; Chávez Alcalá, J.F.; Téllez Ramírez, J.; Magaña Hernández, A. Evaluation of CADI Low Alloyed with Chromium for Camshafts

Application. Metals 2022, 12, 249.

https://doi.org/10.3390/

met12020249

Academic Editor: António

Bastos Pereira

Received: 26 December 2021

Accepted: 25 January 2022

Published: 28 January 2022

Publisher's Note: MDPI stays neutral with regard to jurisdictional claims in published maps and institutional affiliations.

Copyright: (C) 2022 by the authors. Licensee MDPI, Basel, Switzerland. This article is an open access article distributed under the terms and conditions of the Creative Commons Attribution (CC BY) license (https:// creativecommons.org/licenses/by/ $4.0 /)$.

\begin{abstract}
Different processing routes have been developed to increase the strength and hardness of camshafts for automotive applications. In this work, two carbidic austempered ductile irons (CADIs), alloyed with 0.2 and $0.4 \mathrm{wt} \% \mathrm{Cr}$, were evaluated to determine their suitability in the camshaft production by microscopy techniques and mechanical tests. The CADIs were produced at austempering temperatures of 265 and $305^{\circ} \mathrm{C}$, during 30,60, 90, and $120 \mathrm{~min}$. The microstructural characterization was carried out by optical microscopy, while Rockwell C Hardness, tensile, Charpy impact, and block-on-ring wear loss tests were evaluated for mechanical characterization from the camshaft and standard keel block. The volume fraction of high-carbon austenite was determined for the heat treatment conditions by X-ray diffraction measurements. The process window was found in the range from 60 to $120 \mathrm{~min}$, for both austempering temperatures, while the highest amount of ausferrite was obtained at $90 \mathrm{~min}$. The formation of carbides was increased as the chromium content was increased. The highest hardness $(49 \mathrm{HRC})$ and wear resistance $\left(0.252 \mathrm{~mm}^{3}\right)$ were obtained for the lower austempering temperature $\left(265^{\circ} \mathrm{C}, 90 \mathrm{~min}\right)$ and higher chromium content $(0.4 \%)$. The highest austempering temperature $\left(305^{\circ} \mathrm{C}, 90 \mathrm{~min}\right)$ and lowest chromium content $(0.2 \%)$ allow for obtaining the highest toughness (22.91 J) and elongation (4.2\%), while the highest tensile strength (1027 MPa) was obtained for the CADI containing $0.2 \% \mathrm{Cr}$ heat-treated to $265{ }^{\circ} \mathrm{C}$.
\end{abstract}

Keywords: camshaft; CADI; window process; ausferrite; microstructure; mechanical properties; chromium

\section{Introduction}

A ductile cast iron that has been treated by austempering heat treatment is called ADI, the metallic matrix, as a result of the austempering, was denominate ausferrite, which is composed of high-carbon austenite $\left(\gamma_{\mathrm{HC}}\right)$ and acicular ferrite $\left(\alpha_{\mathrm{Ac}}\right)$ with graphite nodules [1]. The mechanical properties obtained from the as-cast process, such as high yield and tensile strength, hardness, and impact energy, are improved by the applying of the austempering heat treatment [2]. Carbidic austempered ductile iron (CADI) is a ductile cast iron containing carbides that are subsequently austempered to produce an ausferritic matrix with carbides. This process creates components that have high hardness and wear resistance characteristics [3]. CADI exhibits an excellent combination of wear resistance and hardness with low impact energy; it is an economical substitute for wrought or forged steel and has been used more and more in automobile, mining, railway, and agricultural machinery sectors [4]. The carbides can be introduced by different methods; however, the most common is by adding carburizers elements $(\mathrm{Cr}, \mathrm{V}, \mathrm{Mo}$, and $\mathrm{B})$ to the iron melt [5]. The used process to obtain CADI, in essence, is the same as the one to obtain ADI, which starts with the austenitizing at temperatures, in the range from 850 to $950{ }^{\circ} \mathrm{C}$ and during a certain time, to transform the as-cast matrix into unstable austenite. After austenitizing, 
the sample is quenched quickly in a salt bath to the austempering temperatures, in the range of 250 to $450{ }^{\circ} \mathrm{C}$ and with enough holding time to obtain the ausferritic matrix, and, finally, cooled to room temperature [6,7]. During austempering, two stages take place. In the first stage, unstable austenite $(\gamma)$ transforms into acicular ferrite $\left(\alpha_{\text {Ac }}\right)$ and high-carbon austenite $\left(\gamma_{\mathrm{HC}}\right)$, according to reaction (1) [8].

$$
\gamma \rightarrow \alpha_{\mathrm{Ac}}+\gamma_{\mathrm{HC}}(\text { ausferrite })
$$

If the austempering time continues to increase, the second stage will occur, where the high-carbon austenite $\left(\gamma_{\mathrm{HC}}\right)$ transforms into bainitic ferrite and carbides of the $\mathrm{Fe}_{3} \mathrm{C}$ or $\varepsilon$ types, according to reaction (2); however, this stage is not desired, due to a detriment in the mechanical properties, promoting brittleness [9].

$$
\gamma_{\mathrm{HC}} \rightarrow \alpha+\text { carbide }\left(\mathrm{Fe}_{3} \mathrm{C} \text { or } \varepsilon\right)
$$

The maximum ausferrite amount is obtained between the two stages of austempering; this is at the end of the first stage and onset of the second stage. This period is called the process window (PW), represented by reaction (3) [10].

$$
\text { PW }: \alpha_{\mathrm{Ac}}+\gamma_{\mathrm{HC}}(\text { stable structure })
$$

Chromium was considered to be an alloying element for the improvement of the oxidation resistance by forming an effective oxidation barrier, despite its strong tendency of carbide formation. It is a ferrite stabilizing element, and its solution in ferrite leads to enhancement of its strength and hardness, as well as a reduction of ductility. It has a strong carbide-forming tendency and segregates in eutectic cell boundaries during solidification. Chromium amounts higher than $1 \mathrm{wt}$. \% decrease the graphite nodularity [6]. Chromium also increases the speed of the first stage reaction to reach the processing window faster. In addition, as it is a carbideforming element, it causes the second reaction to also begin sooner. The processing window range will be smaller and close at higher austempering temperatures [6,11]. The role of chromium during the austempering of ductile iron was studied; it was found that the addition of chromium decreases the stability of austenite, promoting the martensite transformation during cooling, increasing the hardness, and reducing elongation [12].

CADI has attracted intensive attention in many areas, such as the railway, mining industry, defense structures, gears, pinions, crankshafts, centrifugal pump blades, transmissions, suspensions, construction equipment, etc. [13]. The camshaft of an internal combustion engine comprises cams with different profiles arranged in different angles to control the opening and closing of intake and exhaust valves. Rotation of the cam, which takes its movement from the crankshaft via chain or a trigger belt, causes its profile to slide against the smooth flat close end of the cylindrical shape, known as the follower [14]. The camshaft is subject to a different mechanism of degradation during the engine functioning, such as stress concentration, corrosion, abrasion, creep, and wear, as a result of contact stresses and temperature operations that can conduce to crack or failure $[14,15]$. If the local stresses generated between the roller followers and cam profile are greater than the elastic limit of the material, there will be severe wear damage, causing a change in the design contour of the cam and failure of the system [16]. Therefore, it is essential to increase the elastic limit of the material at the surface of the cam by hardening its surface. Some studies have been carried out with different materials or heat treatments to improve the hardness of lobes in the camshaft by using gray iron, chilled gray cast iron [17,18], and steel with surface hardening cams of the engine camshaft [19]; however, ductile iron and austempered ductile iron are cheaper materials, suitable for camshaft manufacturing, due to a balanced combination of hardness, toughness, and strength; in this sense, there are different studies about ductile iron camshaft. The microstructure of camshaft lobes obtained by different processing routes was studied. The lobes evaluated were obtained by chilled gray cast iron, gray cast iron with surface remelted, ductile cast iron induction hardened, and powder 
metallurgy. Ductile iron hardened by induction showed the higher hardness on the lobe surface, while the lobe produced by powder metallurgy showed the lowest hardness [20]. The effect of austempering heat treatment and induction surface hardening was evaluated on GGG60 ductile cast iron camshaft. After austempering and hardening, the obtained a metal matrix that was composed of fine martensite, some needles of ferrite, and some regions of untransformed austenite and graphite nodules. The as-cast hardness was increased from 34.8 to $62.4 \mathrm{HRC}$ after the surface hardening treatment [21]. The microstructural features and mechanical properties of ductile iron low alloyed with 0.2 and $0.3 \mathrm{wt} \%$ of vanadium was studied on camshafts. In both ductile irons, the highest carbide formation (less than $1 \mathrm{wt} \%$ ) was principally located in the middle region of the lobes, due to the inverse chill behavior [22]. Later, the camshafts were austempered to 265 and $305^{\circ} \mathrm{C}$ to obtain ADIs. The microstructural evolution and X-ray diffraction measurements allow for determining the process window (PW) during the austempering heat treatment. An ADI, grade 3, was obtained for the ADI alloyed with $0.3 \mathrm{wt} \% \mathrm{~V}$ austempered at $265{ }^{\circ} \mathrm{C}$ [23]. This work aims to evaluate the microstructural and mechanical properties of camshafts lobes of ductile iron and carbidic austempered ductile iron, low alloyed with 0.2 and $0.4 \mathrm{wt} \%$ of chromium to increase the hardness and wear resistance of the camshaft. The microstructural evolution of the austempering heat treatment was held at 265 and $305^{\circ} \mathrm{C}$, at different times. The process window (PW) was determined for the heat treatment conditions by X-ray diffraction measurements. The mechanical properties of tensile strength, hardness, toughness by the Charpy impact test, and wear resistance were evaluated to the austempering time, where the highest high-carbon austenite value was reached.

\section{Materials and Methods}

\subsection{Casting of Ductile Iron Camshafts}

Three ductile irons (DI), identified as DI-U, DI-0.2Cr, and DI-0.4Cr, for camshaft unalloyed and alloyed with $0.2 \mathrm{wt} \% \mathrm{Cr}$ and $0.4 \mathrm{wt} \% \mathrm{Cr}$, respectively, were produced in ARBOMEX S.A de C.V., a Mexican company located at Celaya and Apaseo Guanajuato, as well as El Salto Jalisco, Mexico (specialized in camshafts manufacturing). Iron burrs from machining area (30 $\mathrm{wt} \%)$, low carbon steel (30 wt\%), and cast-iron scrap (balance) were used in base iron melted and homogenized in the range from 1400 to $1440{ }^{\circ} \mathrm{C}$ in a dual-track coreless induction furnace (Inductotherm Corp., Rancocas, NJ, USA) of medium frequency $(300 \mathrm{~Hz})$ inductotherm with $3500 \mathrm{~kW}$ power capacity. The chemical composition was adjusted in a ladle by adding FeSi (70\%), high purity carbon as recarburizing, and $\mathrm{FeCr}(63 \%)$. The alloyed melt was poured into a tundish ladle with $1.05 \mathrm{wt} \% \mathrm{MgFeSi}$ as a nodulizing agent $(45 \% \mathrm{Si}, 7.5 \% \mathrm{Mg}, 0.8 \% \mathrm{Al}, 2.6 \% \mathrm{Ca}$, and $2.48 \%$ rare earth). Afterwards, the melt was poured into a ladle, and it was inoculated with $\mathrm{FeSi}(70 \% \mathrm{Si}+0.8 \% \mathrm{Ca}$ and $3.9 \% \mathrm{Al})$ by the ladle inoculation method. Each of the three cast alloys was poured at $1385-1420{ }^{\circ} \mathrm{C}$ into the phenolic urethane no-bake sand molds casting method, which was previously obtained by a prototype tooling with 12 cavities of camshafts for a V8 engine 5.0 L (FORD company) to obtain about 100 camshafts for each alloy. Figure 1 shows the casting camshaft containing eight lobes. The chemical composition of camshafts was analyzed by an OBLF GS 1000 II emission optic spectrograph (OBLF Gesellschaft für Elektronik und Feinwerktechnik $\mathrm{mbH}$, Witten, Germany), and the reported values are the average of three measurements of each cast alloy. Carbon and sulfur content were analyzed by combustion analysis using a Leco C/S 744 analyzer (LECO Corporation, St. Joseph, MI, USA).

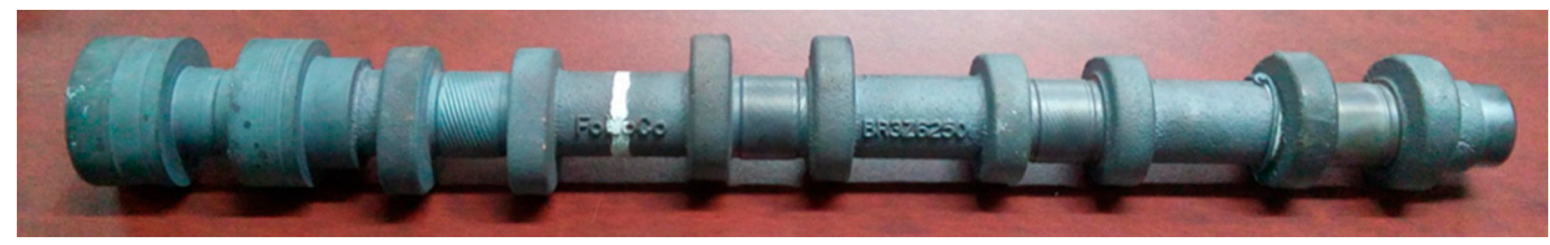

Figure 1. As-cast camshaft containing 8 lobes. 


\subsection{Austempering Heat Treatments}

Four camshafts were randomly selected from each cast alloy, and the lobes were sectioned on the cross-section through the metallography fine cuter disc and liquid cooling for the austempering heat-treatment process. Figure $2 \mathrm{a}$ shows a complete lobe taken from the camshaft, while Figure $2 b, c$ show the three regions analyzed for the microstructural characterization for the as-cast condition and carbidic austempered ductile iron produced, respectively.

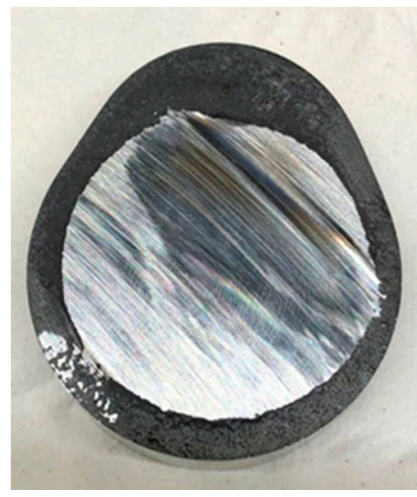

(a)

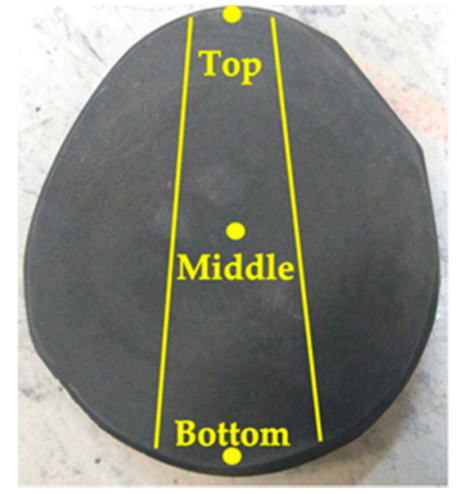

(b)

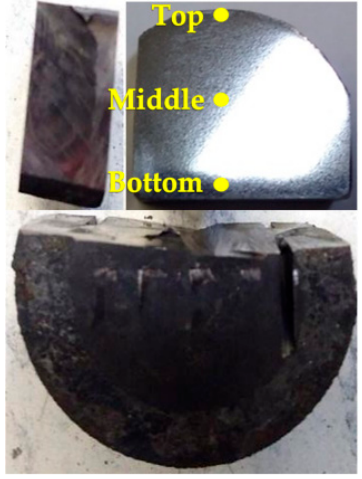

(c)

Figure 2. Lobe sectioned for microstructural characterization. (a) Lobe sample after cutting, (b) regions analyzed for the as-cast condition, and (c) regions analyzed for the CADI produced.

Two austempering heat treatments were carried out in two electric furnaces (Thermo Fisher Scientific, Waltham, MA, USA) with a heating rate of $10{ }^{\circ} \mathrm{C} / \mathrm{min}$, based on the austempering heat treatment cycles of Figure 3. The samples taken from the lobes were austenitized at $900 \pm 5{ }^{\circ} \mathrm{C}$ with a residence time of $180 \mathrm{~min}$. Then, the samples were quickly transferred to a second furnace containing a salt bath melt $\left(50 \% \mathrm{KNO}_{3}\right.$ and $50 \%$ $\mathrm{NaNO}_{3}$ ) at 265 or $305 \pm 5{ }^{\circ} \mathrm{C}$. The soaking time was set at 30,60, 90, and $120 \mathrm{~min}$; then, the samples were water-cooled at room temperature. The austempering temperatures were chosen to obtain higher hardness and wear resistance for both austempering temperatures; additionally, a higher toughness was expected for the highest austempering temperature.

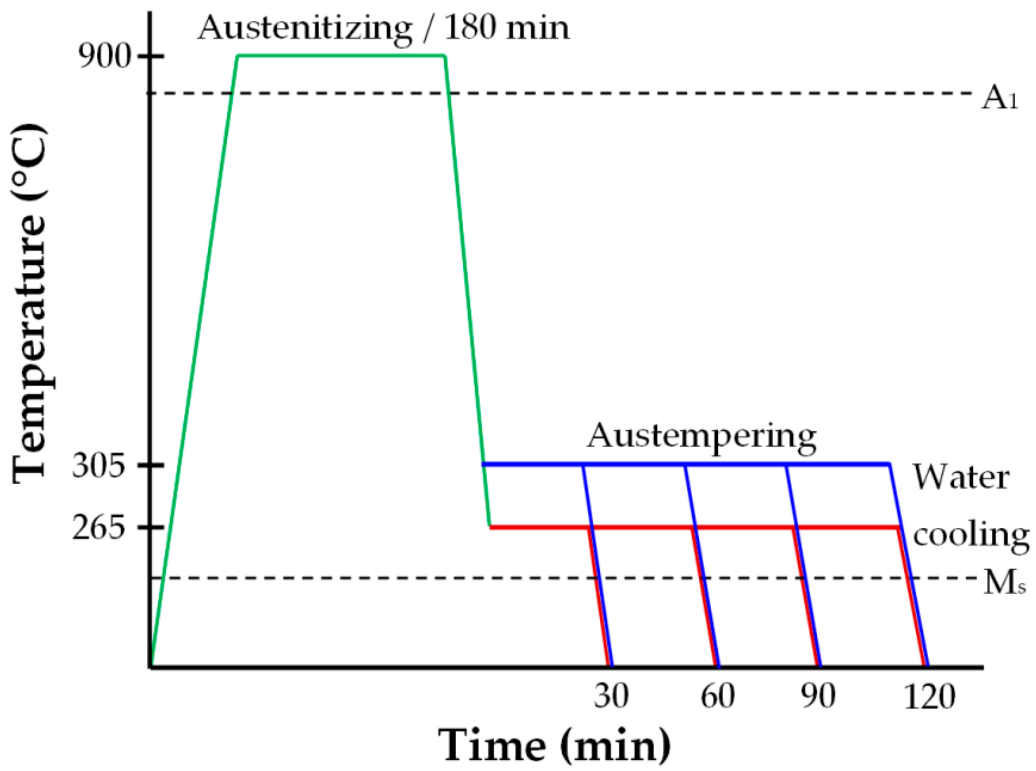

Figure 3. Austempering heat treatment cycles for temperatures of 265 and $305^{\circ} \mathrm{C}$. 


\subsection{Microstructural Characterization}

The produced ductile irons (DI) and carbidic austempered ductile irons (CADIs) were analyzed by conventional metallography by using manual grinding and polishing to reveal the graphite features as nodularity (\%), nodule count (part $/ \mathrm{mm}^{2}$ ), and nodule size $(\mu \mathrm{m})$. The nodularity, by using object area, is defined in ASTM A247 as: $\%$ nodularity $=\left[\right.$ Area $_{\text {acceptable particles }} /\left(\right.$ Area $_{\text {acceptable }}+$ unacceptable particles $\left.)\right] \times 100$. Particles with a diameter smaller than $10 \mu \mathrm{m}$ were neglected in the nodule count determination [24]. The samples were etched with nital 3\% to reveal phases and microconstituents. The volume fraction of the carbides was determined by etching the samples with a solution of ammonium persulfate. The micrographs were obtained with a light microscopy Olympus PMG-3 model (Olympus Corporation, Center Valley, PA, USA) at 100 X, based on the ASTM 247 standard and Image J software (NIH, Bethesda, MD, USA). The reported results for the optical microscopy analysis were the average of three micrographs obtained from three different regions (shown in Figure $2 b, c$ ) for the ductile irons and the CADIs produced, respectively. Scanning electronic microscopy with energy dispersive spectroscopy (SEMEDS) was used to analyze the carbides contained in the CADIs. Images were taken with backscattering electrons of $20 \mathrm{kV}$ in a scanning electron microscope (SEM) JEOL model 6300 (JEOL, Peabody, CA, USA).

The phases obtained by the austempering heat treatments (acicular ferrite and highcarbon austenite) were analyzed by X-ray diffraction measurements, using a Bruker D8 Focus diffractometer (Bruker, Billerica, MA, USA), with monochromatic radiation $\mathrm{Cu} \mathrm{K} \alpha_{1}$, working in $\theta / 2 \theta$ configuration. Data were obtained by a step size of $0.02^{\circ}$ in a counting time of $2^{\circ} / \mathrm{min}$, in the range from 35 to $100^{\circ}$. The model utilized determines the volume fraction of high-carbon austenite, according to Equation (4), and integrated intensities of the peak of ferrite and austenite for each sample [25]:

$$
\gamma_{\mathrm{HC}}=\frac{1.4 \mathrm{I}_{\gamma}}{\mathrm{I}_{\alpha}+1.4 \mathrm{I}_{\gamma}}
$$

where $\mathrm{I} \gamma$ and $\mathrm{I} \alpha$ are the intensities of the (hkl) reflections in the $\alpha$ and $\gamma$ phases, determined with Equations (5) and (6), respectively.

$$
\begin{gathered}
\mathrm{I}_{\gamma}=\frac{\mathrm{I}_{\gamma 220}+\mathrm{I}_{\gamma 311}}{2} \\
\mathrm{I}_{\alpha}=\mathrm{I}_{\alpha 211}
\end{gathered}
$$

\subsection{Mechanical Properties}

The mechanical tests were performed at room temperature; the geometry and size of specimens were obtained following standard specifications ASTM E 18, ASTM E 8, ASTM A 327, and ASTM G 77 for hardness (HRC), tensile, unnotched impact, and block-on-ring wear tests, respectively. Samples for mechanical testing were obtained from the camshafts produced and keel block castings, based on the standard specification ASTM A 536, as can be observed from Figure 4. Hardness and wear measurements were taken from the crosssection of the lobes, while the shaft of the camshaft was used to obtain samples for Charpy and tensile tests. The samples obtained from the as-cast keel block were used mainly for the tensile test. The CADIs mechanical properties were evaluated from austempered samples, based on the heat treatment cycles shown in Figure 3, and the soaking time was chosen according to the highest high-carbon austenite value obtained by XRD measurements. The mechanical results show the average of the measurements and standard deviation for each casting alloy and CADI produced. 


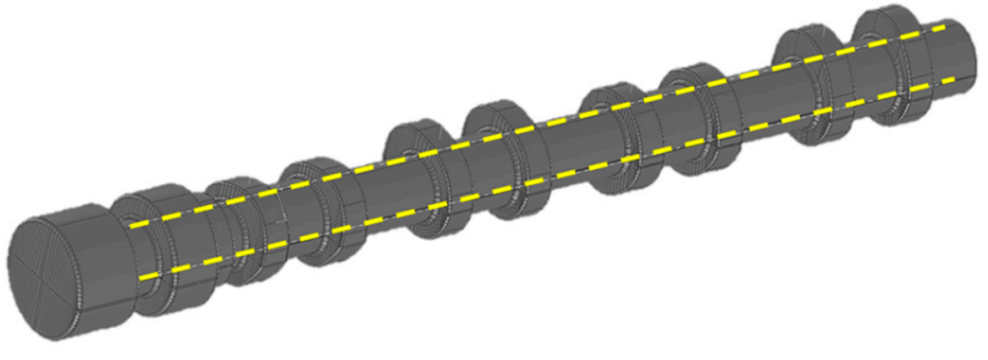

(a)

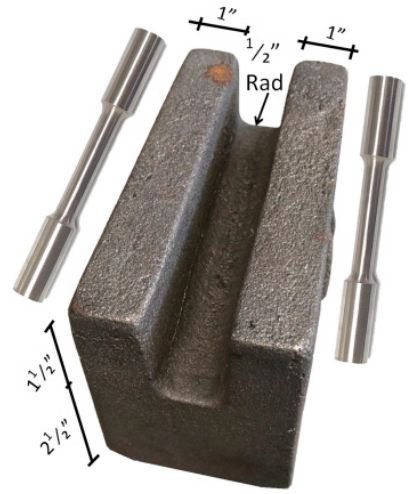

(b)

Figure 4. Samples obtained for mechanical tests from the (a) camshaft and (b) keel block castings.

Rockwell $\mathrm{C}$ hardness measurements were made on the polished surfaces of the ascast cross-section of four camshaft lobes by a Wilson 3T TBRB hardness tester (Buehler, Lake Bluff, IL, USA) applying a load of $150 \mathrm{~kg}$ while for CADIs; the hardness measurements were carried out to the four austempering times evaluated. The reported results represent the average of at least five measurements. Tensile testing was carried out in a universal testing machine Shimadzu (Shimadzu Corporation, Nakagyo-ku, Kyoto, Japan) of 100 kN and $10 \mathrm{~mm} / \mathrm{min}$ cross-head speed. Four specimens from each casting alloy and CADI heat-treated to $90 \mathrm{~min}$ were tested, and the average of the measurements was reported. The impact test was carried out in a Tinius Olsen Charpy impact machine (Tinius Olsen TMC, Hursham, PA, USA) on unnotched samples. The maximum energy of the machine was $220 \mathrm{~J}$, and the impact velocity was $4.5 \mathrm{~m} / \mathrm{s}$. Four specimens from each cast alloy and CADIs were tested. The wear resistance was evaluated in a TE 53SLIM multi-purpose friction machine (Tinius Olsen TMC, Hursham, PA, USA) on cube samples of $12.5 \mathrm{~mm}$, with machined flat surfaces without lubricant. A metal ring, with a hardness of $63 \mathrm{HRC}$, rotates on the surface of the sample to $300 \mathrm{rpm}$, applying a load of $45 \mathrm{~N}$ for a distance of $100 \mathrm{~m}$. The wear results were obtained with Equation (7):

$$
\text { Scar volume }=\frac{\mathrm{D}^{2} \mathrm{t}}{8}\left[2 \sin ^{-1} \frac{\mathrm{b}}{\mathrm{D}}-\sin \left(2 \sin ^{-1} \frac{\mathrm{b}}{\mathrm{D}}\right)\right]
$$

where $\mathrm{D}$ is the diameter of the ring $(\mathrm{mm}), \mathrm{t}$ is the block width $(\mathrm{mm})$ and $\mathrm{b}$ is the width average of the scar (mm).

\section{Results}

\subsection{Chemical Composition}

The chemical composition of unalloyed and alloyed camshafts with 0.2 and $0.4 \mathrm{wt} \%$ $\mathrm{Cr}$ is shown in Table 1. The chemical composition corresponds to hyper-eutectic ductile irons, based on the carbon equivalent determination, where the magnesium residual is in the range expected to achieve an adequate nodule formation [26]. The manganese content promotes austemperability; however, the window process is narrowed at austempering temperatures higher than $320^{\circ} \mathrm{C}$ [27]. On the other hand, it is expected that copper increases the volume fraction of high-carbon austenite at concentrations less than $1 \mathrm{wt} \% \mathrm{Cu}$, as well as the austemperability [28]. Therefore, chromium is the main difference in the chemical composition of the ductile irons produced. It has been reported [28] that chromium addition decreases the process window range, especially at higher austempering temperatures; this means that the speed of the first stage reaction is increased, as well as the beginning of the second reaction, due to its carbide forming ability. 
Table 1. Chemical composition for unalloyed and alloyed camshafts with 0.2 and $0.4 \mathrm{wt} \% \mathrm{Cr}$.

\begin{tabular}{|c|c|c|c|c|c|c|c|c|c|c|c|c|c|}
\hline Sample & $\mathrm{C}$ & Si & Mn & $\mathbf{P}$ & $S$ & Mg & V & $\mathrm{Cr}$ & $\mathrm{Ni}$ & $\mathrm{Al}$ & $\mathrm{Cu}$ & Mo & $\mathrm{CE}^{1}$ \\
\hline DI-U & 3.61 & 2.36 & 0.83 & 0.015 & 0.008 & 0.046 & 0.008 & 0.043 & 0.103 & 0.013 & 0.879 & 0.03 & 4.40 \\
\hline $\begin{array}{c}\text { DI- } \\
0.2 \mathrm{Cr}\end{array}$ & 3.64 & 2.41 & 0.94 & 0.015 & 0.013 & 0.047 & 0.011 & 0.23 & 0.114 & 0.014 & 0.961 & 0.093 & 4.44 \\
\hline $\begin{array}{c}\text { DI- } \\
0.4 \mathrm{Cr}\end{array}$ & 3.56 & 2.47 & 0.94 & 0.016 & 0.013 & 0.048 & 0.010 & 0.42 & 0.118 & 0.014 & 0.954 & 0.095 & 4.38 \\
\hline
\end{tabular}

Balance Fe. ${ }^{1}$ Carbon equivalent $=\% \mathrm{C}+1 / 3(\% \mathrm{Si}+\% \mathrm{P})$.

\subsection{Microstructural Characterization of Ductile Irons}

The microstructural characterization was carried out on the two ductile irons alloyed with 0.2 and $0.4 \mathrm{wt} \% \mathrm{Cr}$, and a similar behavior was observed for the two alloys. Figure 5 shows the microstructures of the DI-0.4Cr sample analyzed in the top, middle, and bottom zones of the lobe (see Figure $2 b$ ) for the as-cast condition, etched with nital and ammonium persulfate. It is evident from the as-cast condition that the top zone exhibits the highest nodule count with the lowest nodule size, while the middle zone shows the opposite behavior. In general, thicker sections show a low nodule count with big size, due to a different cooling rate during solidification [29]. The matrix is fully pearlitic, and the white regions are attributed mainly to carbides, which are clearer observed in the micrographs etched with ammonium persulfate. The graphite features and microstructure of the DI$0.2 \mathrm{Cr}$ sample are similar to the DI-0.4Cr sample, and the results are shown in Figure A1 from Appendix A.

As-cast
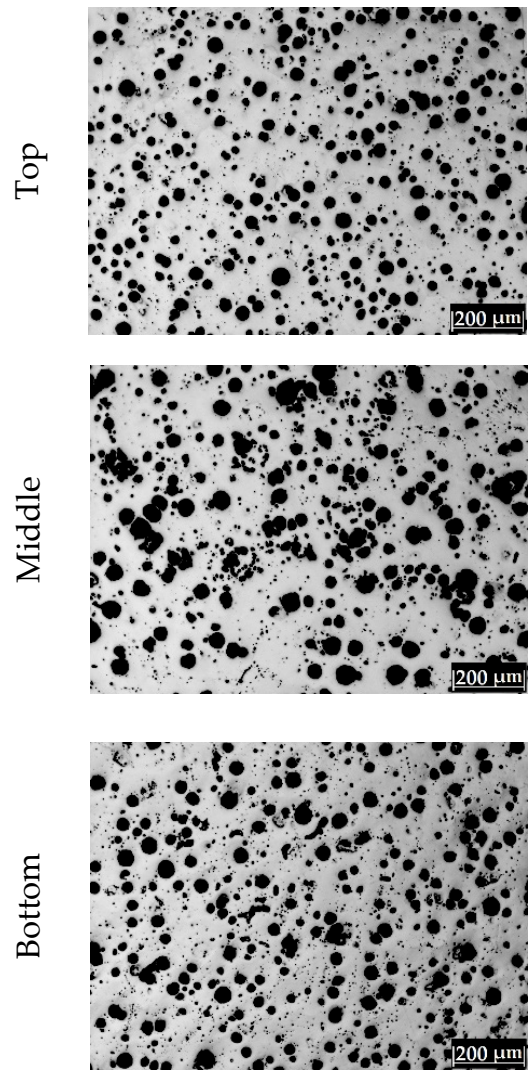

(a)
Nital
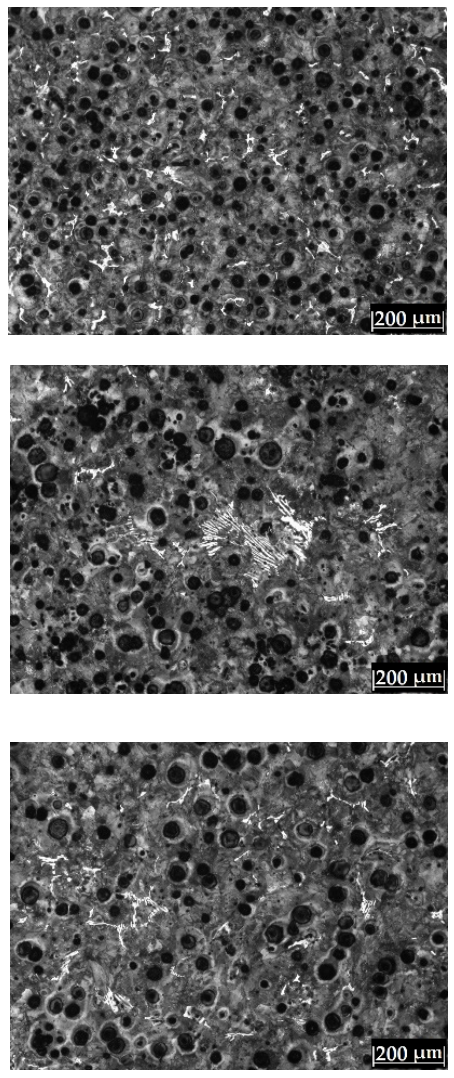

(b)
Ammonium persulfate
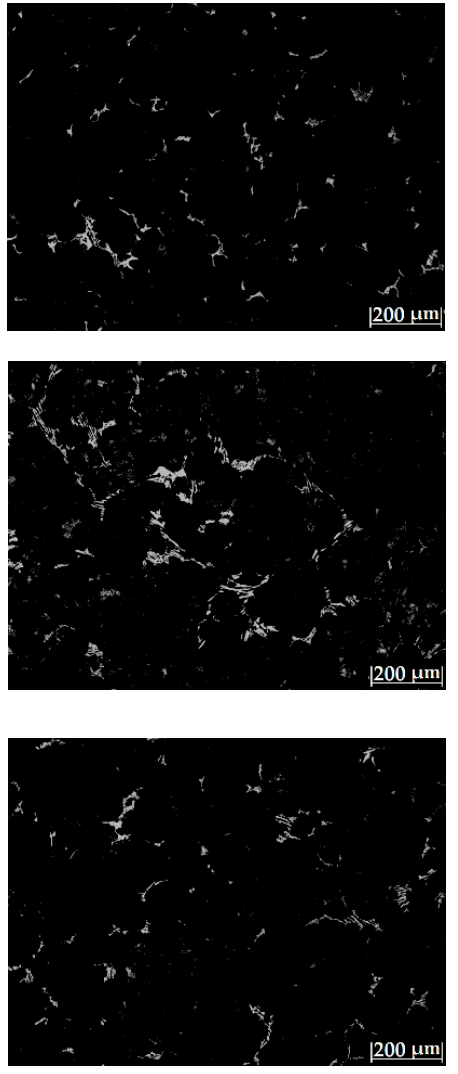

(c)

Figure 5. Microstructure of DI-0.4Cr sample for the top, middle, and bottom zones for (a) as-cast, (b) etched with nital, and (c) etched with ammonium persulfate conditions. 
Table 2 shows the graphite nodule features and phases formed during solidification for the ductile irons manufactured. These results represent the average of the whole lobe for four lobes distributed alongside the camshaft. It is observed that the nodularity decreases from $75.04 \%$ to $71.30 \%$, nodule count increases from 223 to $283 \mathrm{part} / \mathrm{mm}^{2}$, and nodule size decreases from 29.06 to $27.27 \mu \mathrm{m}$ when the chromium content was increased from 0.2 to $0.4 \mathrm{wt} \% \mathrm{Cr}$. These results match with those reported in a study on the effect of chromium addition during the austempering of ductile iron [12]. It was observed that the highest carbide formation is located in the middle of the lobes, instead of the external parts of the lobes. This behavior is related to the inverse chill, where there is a segregation of carbideforming elements to the middle zone of the camshaft increasing the concentration of these elements in the last liquid to solidify promoting eutectic iron carbide formation [30].

Table 2. Graphite features and volume fraction of phases formed for camshafts unalloyed and alloyed with 0.2 and $0.4 \% \mathrm{Cr}$.

\begin{tabular}{cccc}
\hline Characteristics & DI-U & DI-0.2Cr & DI-0.4Cr \\
\hline Nodularity (\%) & $85.17 \pm 2.64$ & $75.04 \pm 1.61$ & $71.30 \pm 3.31$ \\
Nodule count & $155 \pm 28.67$ & $223.38 \pm 26.15$ & $283.54 \pm 17.50$ \\
(particles $/ \mathrm{mm}^{2}$ ) & $32.49 \pm 3.69$ & $29.06 \pm 1.79$ & $27.24 \pm 3.02$ \\
Nodule size $(\mu \mathrm{m})$ & $12.84 \pm 0.55$ & $14.57 \pm 1.25$ & $17.04 \pm 1.97$ \\
Graphite (\%) & $5.3 \pm 0.20$ & $0.33 \pm 0.18$ & $1.56 \pm 0.19$ \\
Ferrite $(\%)$ & $81.70 \pm 0.20$ & $84.45 \pm 0.30$ & $78.53 \pm 0.24$ \\
Pearlite (\%) & $0.156 \pm 0.04$ & $0.65 \pm 0.12$ & $2.87 \pm 0.92$ \\
Carbides $(\%)$ & & \\
\hline
\end{tabular}

It is observed that the microstructure is mainly constituted by pearlite and very few amounts of ferrite. The ferrite amount was slightly increased as the chromium content was increased; however, the unalloyed ductile iron showed the highest amount of ferrite, due to lower amounts of forming carbide elements, such as chromium and manganese, in their chemical composition. In addition, as expected the volume fraction of graphite and carbides are increased when the chromium amount is increased.

\subsection{Microstructural Characterization of CADIs}

Two austempering heat treatments were carried out to obtain CADIs low alloyed with 0.2 and $0.4 \mathrm{wt} \% \mathrm{Cr}$ at 265 and $305^{\circ} \mathrm{C}$, which were denominated as CADI-0.2Cr-265, CADI0.4Cr-265, CADI-0.2Cr-305, and CADI-0.4Cr-305. The microstructural characterization was evaluated for the four CADIs produced, and a similar microstructural evolution was observed for the two alloys low alloyed with chromium. Figures 6 and 7 show the microstructural evolution for the CADIs, containing $0.4 \mathrm{wt} \% \mathrm{Cr}$, which were heat-treated at $265{ }^{\circ} \mathrm{C}$ and $305^{\circ} \mathrm{C}$, respectively, at different times (CADI-0.4Cr-265 and CADI-0.4Cr-305) and three regions analyzed, based on Figure 2c. The microstructural evolution of CADIs, containing $0.2 \mathrm{wt} \% \mathrm{Cr}$ heat-treated to 265 and $305^{\circ} \mathrm{C}$ and different austempering times, are reported in Figures A2 and A3, respectively, from Appendix A.

The microstructures in Figures 6 and 7 show a mixture of dark needles, constituted by acicular ferrite, high-carbon austenite, and white blocks of carbides. It is observed that the austenitizing of $180 \mathrm{~min}$, applied in the heat treatment, was enough to dissolve mainly the pearlite forming unstable austenite; however, the carbides obtained from as-cast were not dissolved. This behavior on undissolved carbides has been previously reported for CADIs alloyed with chromium in the range from 1 to $2.5 \mathrm{wt} \% \mathrm{Cr}$, the volume fraction of chromium carbides obtained was in the range of $5-21 \%$, respectively [31]. The carbide content after the heat treatment remained mostly unchanged, due to the high thermodynamic stability of carbides alloyed with chromium. The microstructural evolution of CADI-0.4Cr-265 and CADI-0.4Cr-305 in the three regions analyzed of the camshaft lobe is shown in Figures 6 and 7. The CADI-0.4Cr-265 samples show that at an austempering time of $30 \mathrm{~min}$, the microstructure is composed principally of martensite with small regions of ausferrite and white carbide blocks. For short periods, the unstable austenite transforms, mainly to 
martensite (during cooling at room temperature) and small regions of ausferrite. When the austempering time was increased to $60 \mathrm{~min}$, the unstable austenite had more time to nucleate and grow to the ausferrite phase; as a consequence, the volume fraction of martensite decreased, and the as-cast carbides remained. The microstructures obtained in the range from 30 to 60 min correspond to the first stage of the austempering reaction. At the austempering time of $90 \mathrm{~min}$, the microstructure is composed principally of ausferrite and carbides. At the longest austempering time of $120 \mathrm{~min}$, the microstructure consists of ferrite and precipitated carbides, based on the phase transformation of the high-carbon austenite, corresponding to the second stage in the austempering reaction [32]. It was observed from the microstructural evolution that for the austempering time of $90 \mathrm{~min}$, the microstructure is mainly constituted of ausferrite, so this time was considered to carry out the heat treatments to evaluate the mechanical properties. Therefore, the process window occurs between 60 and $120 \mathrm{~min}$ of isothermal heat treatment, as described in reaction 3. Similar behavior on the microstructural evolution during austempering heat treatment was reported on ADIs alloyed with different nodule counts [33]. The phase transformations were similar for both the alloys and austempering temperatures evaluated. It has been reported $[34,35]$ that high austempering temperatures promote that the process window becomes shifted towards the shorter austempering times, narrowing the PW. However, the difference of $40{ }^{\circ} \mathrm{C}$, for the austempering temperatures evaluated in this work, does not evidence a narrowing in the PW; thus, the PW was set in the range from 60 to 120 min, and 90 min was the time where the highest ausferrite amount was obtained.

Top
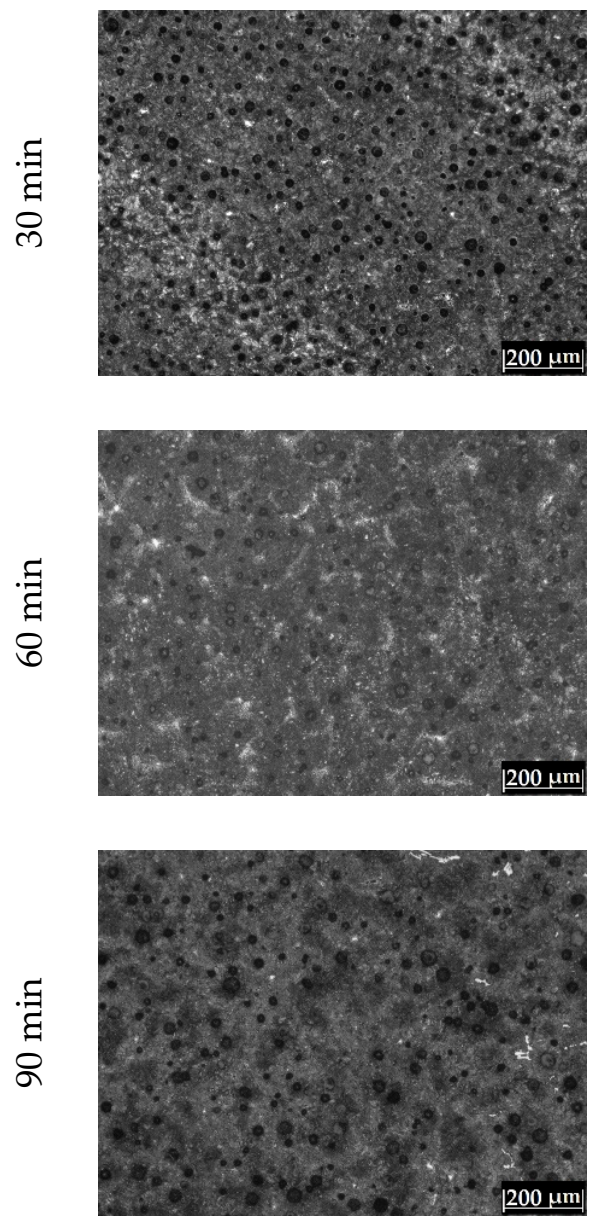

Middle
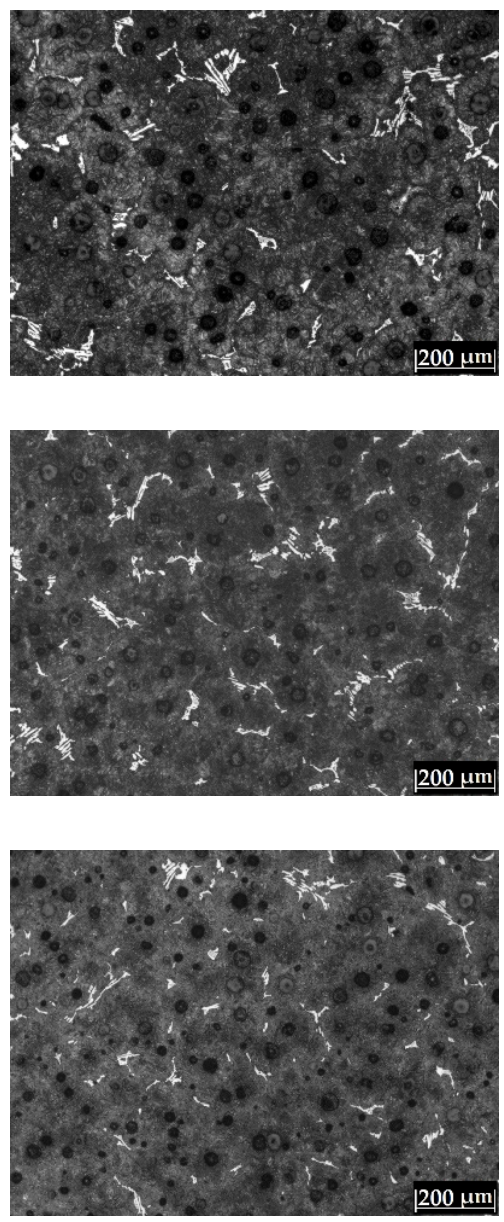

Bottom
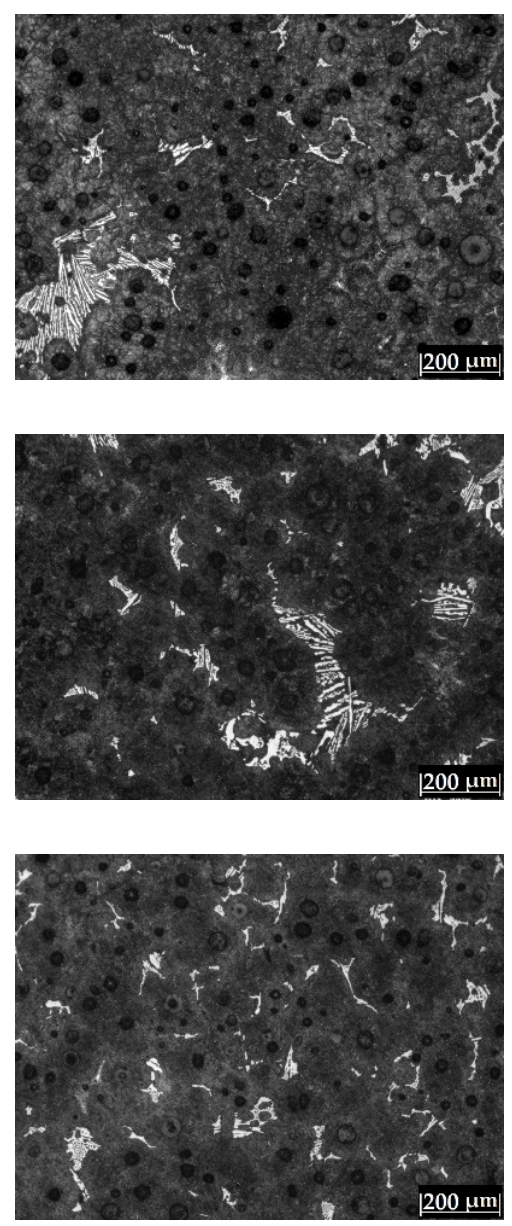

Figure 6. Cont. 

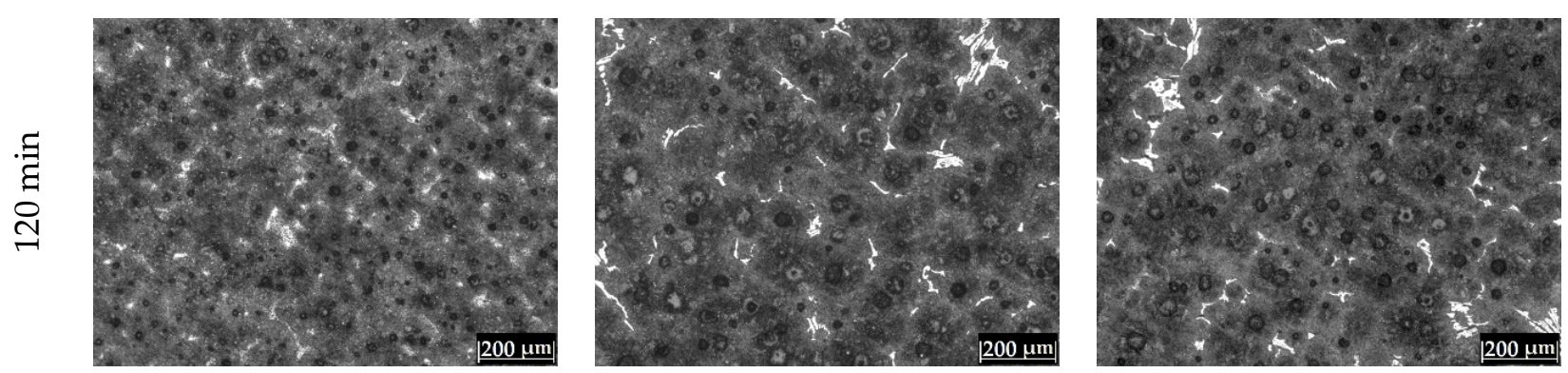

Figure 6. Microstructural evolution for the CADI-0.4Cr-265 sample at the austempering times of 30, 60,90 , and $120 \mathrm{~min}$ for the three regions analyzed.

Top
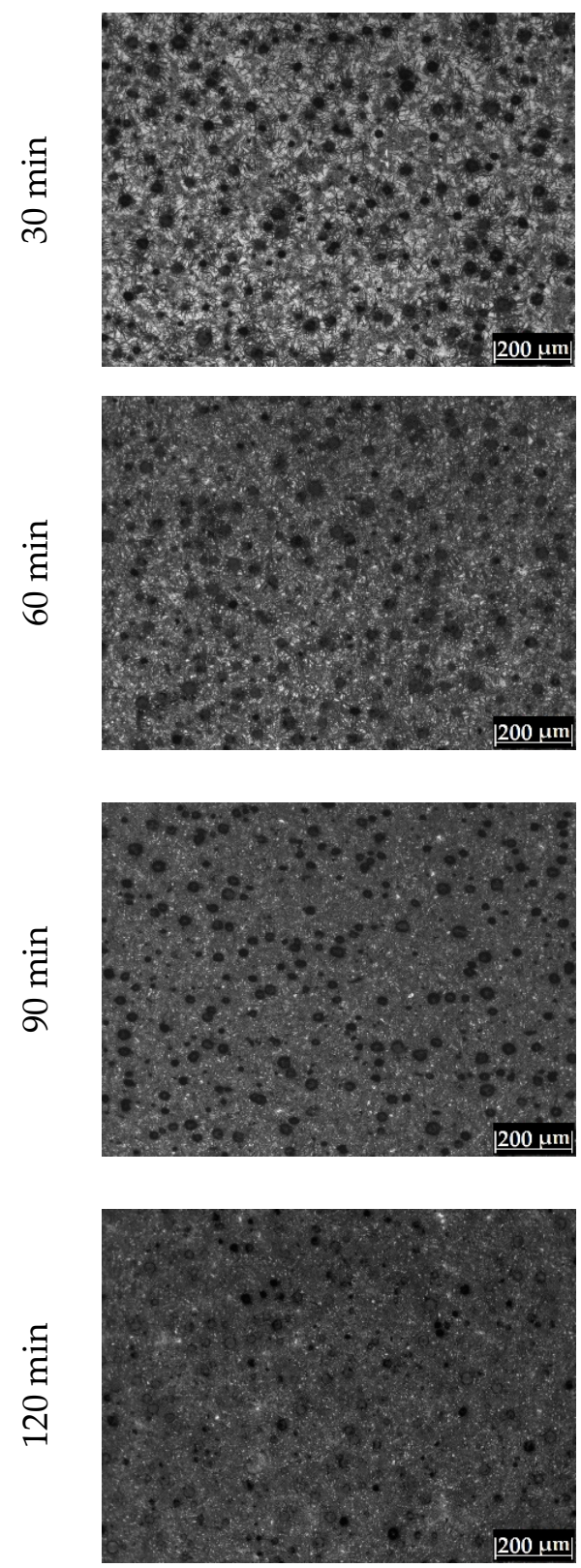

Middle
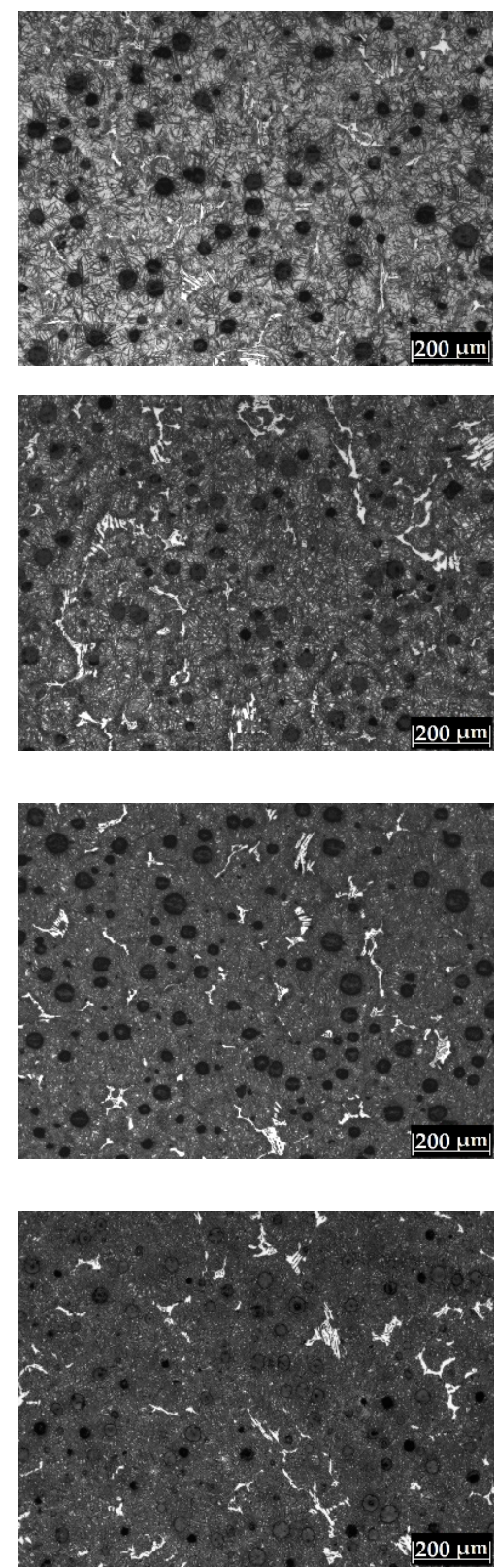

Bottom
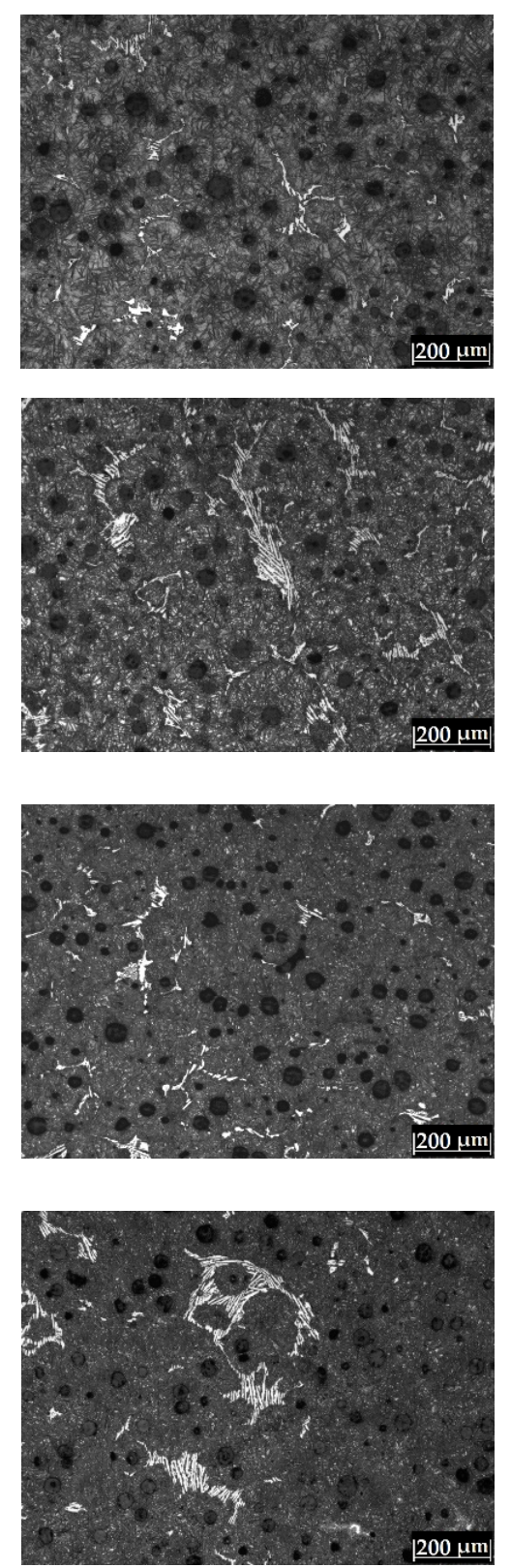

Figure 7. Microstructural evolution for the CADI-0.4Cr-305 sample at the austempering times of 30, 60,90 , and $120 \mathrm{~min}$ for the three regions analyzed. 
However, a microstructural change was observed between CADIs heat-treated to low and high austempering temperatures. Figure 8 shows the microstructure by SEM of the CADIs containing 0.2 and $0.4 \mathrm{wt} \% \mathrm{Cr}$ for the austempering temperatures of 265 and $305{ }^{\circ} \mathrm{C}$ and 90 min of soaking time. A microstructure of fine ausferrite was observed; this is a mixture of fine acicular ferrite and a few blocks of high-carbon austenite (Figure 8a) for the CADIs low alloyed with chromium heat-treated to $265^{\circ} \mathrm{C}$. The acicular ferrite is formed from unstable austenite by nucleation and the grain growth process in solid state, and the low austempering temperature allow to faster cooling, increasing the ferrite nucleation. When the austempering temperature was increased to $305^{\circ} \mathrm{C}$, the microstructure changed to coarse ausferrite with a higher volume fraction of high-carbon austenite. For this case, the cooling is slower; thus, less ferrite acicular was nucleated and the volume fraction of high-carbon austenite was increased, obtaining coarse ausferrite [36,37]. It was reported that a feathery ausferrite was obtained at austempering temperatures higher than $350{ }^{\circ} \mathrm{C}$, while fine ausferrite with needle morphology was obtained for austempering heat treatments lower than $325{ }^{\circ} \mathrm{C}$ [38]. It is evident from the microstructures of Figure 8 that the ausferrite obtained in CADIs alloyed with $0.4 \mathrm{wt} \% \mathrm{Cr}$ are finer than those obtained in CADIs containing $0.2 \mathrm{wt} \% \mathrm{Cr}$ at the same temperature. This behavior is related to the higher nodule count and carbides presented for the CADI containing the higher chromium content. The adding of carbide formers, such as as Mo and $\mathrm{Cr}$, increased the carbide formation, and the amount of ferrite acicular increased and become finer $[39,40]$. On the other hand, the increase of the nodule count allows for obtaining finer and more homogeneous microstructures [41].

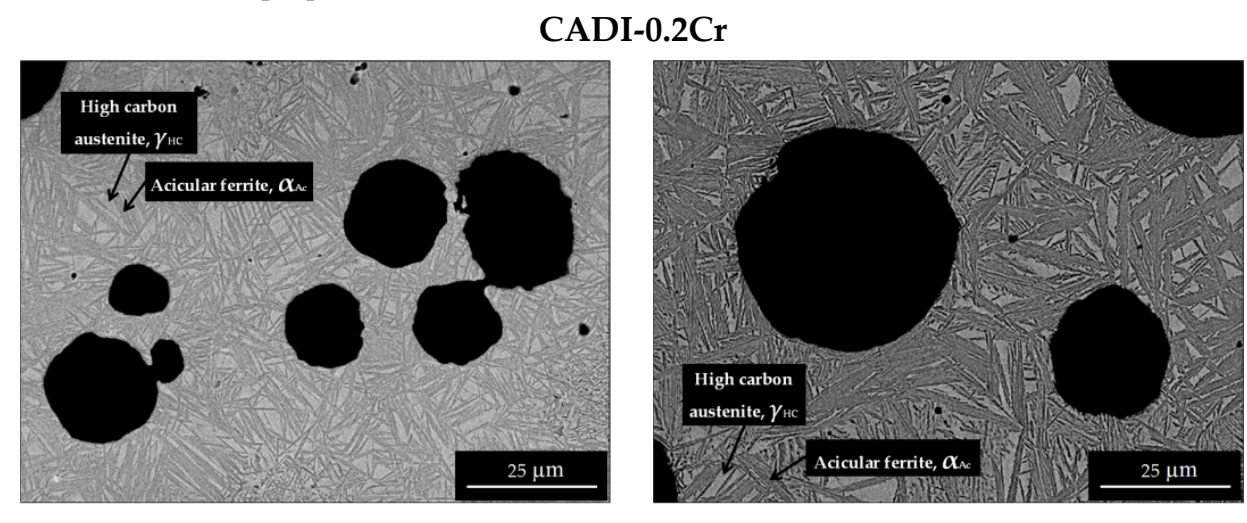

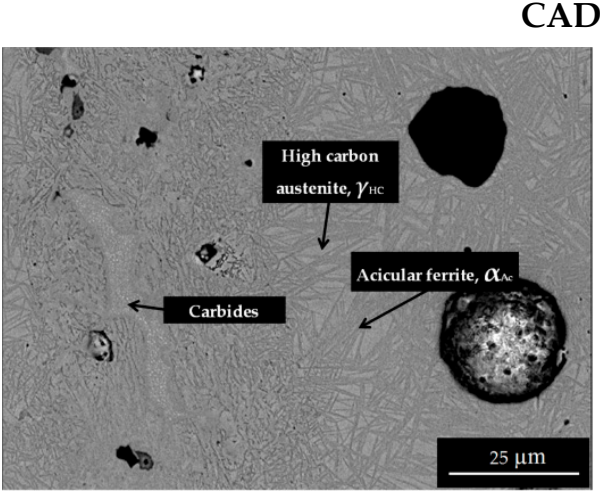

(a)

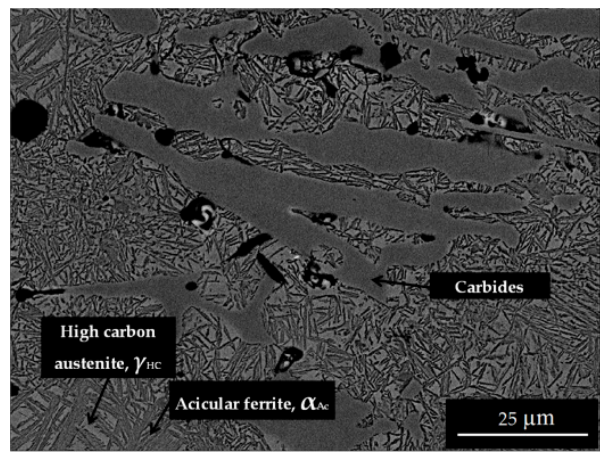

(b)

Figure 8. Microstructure of CADI alloyed with 0.2 and $0.4 \mathrm{wt} \% \mathrm{Cr}$ heat-treated to (a) $265{ }^{\circ} \mathrm{C}$ and (b) $305^{\circ} \mathrm{C}$ for $90 \mathrm{~min}$.

Figure 9 shows the results of scanning electron microscopy (SEM) and energy dispersive spectroscopy analysis (EDS) of angular shapes, identified as carbides regions in the CADIs produced. From the microanalysis results, it can be seen a high iron and chromium concentration into the carbide particle, while the ausferritic matrix shows a homogeneous concentration of the alloying elements, such as silicon, carbon, iron, manganese, and lower 
amounts of chromium. The angular carbides were formed during and after solidification of the cast alloy, and austempering heat treatment did not produce the formation of dot-like carbides. In the solidification process of the $\mathrm{Fe}-\mathrm{Cr}-\mathrm{C}$ alloys, the chromium goes entirely into the carbide phase as $\mathrm{Fe}_{3} \mathrm{C}$ type for the small chromium additions evaluated [42].
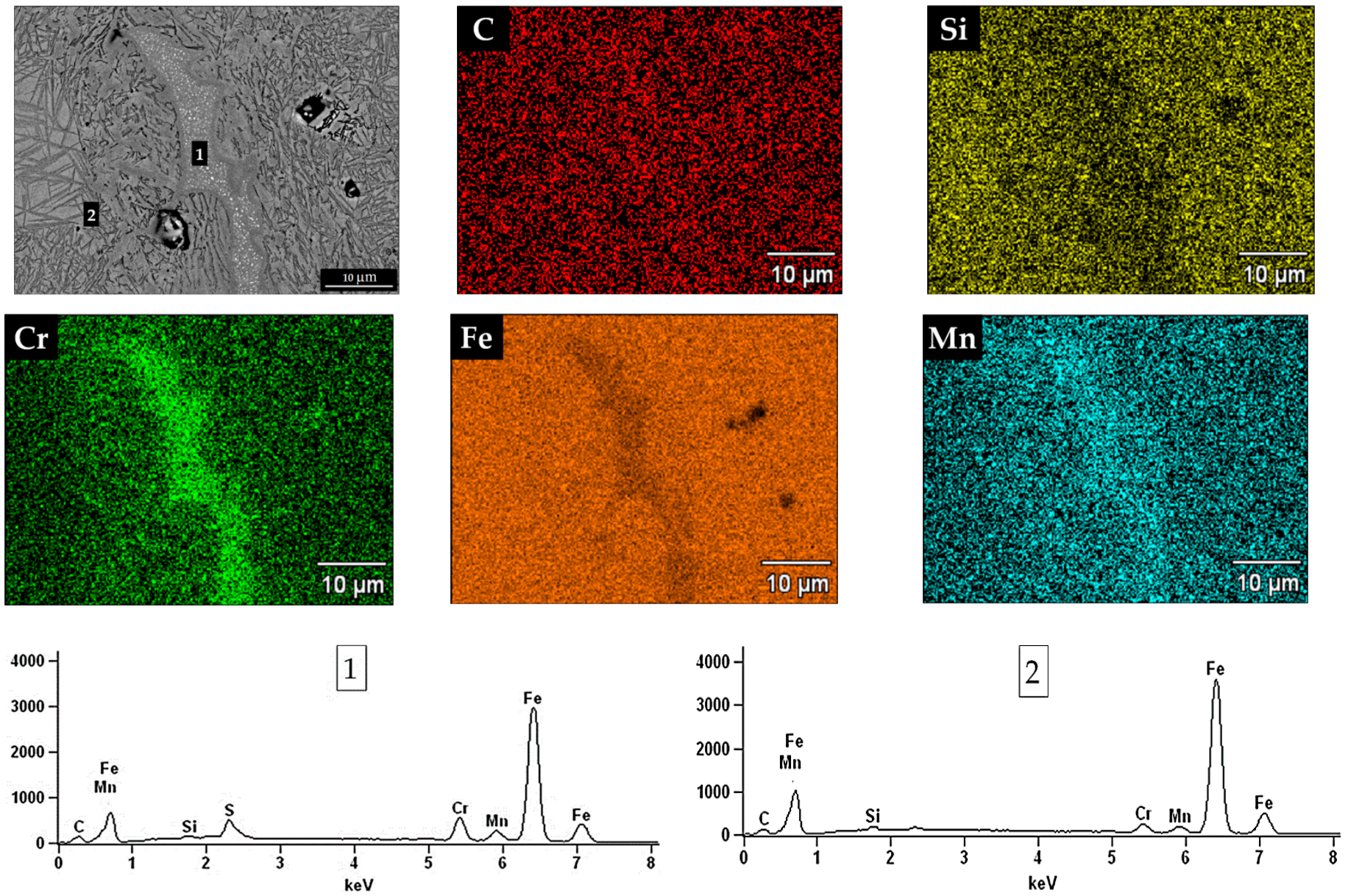

Figure 9. Carbide image by SEM-EDS and X-ray mapping of carbon, silicon, chromium, iron, and manganese of the CADI alloyed with $0.4 \mathrm{wt} \% \mathrm{Cr}$ heat-treated to $265^{\circ} \mathrm{C}$ for $90 \mathrm{~min}$.

\subsection{Volume Fraction of High-Carbon Austenite}

The X-ray diffraction patterns of the CADIs alloyed with 0.2 and $0.4 \mathrm{wt} \% \mathrm{Cr}$, at 265 and $305{ }^{\circ} \mathrm{C}$, for the austempering times of 30, 60, 90, and $120 \mathrm{~min}$, are shown in Figure 10. It is observed that the planes (111), (200), (220), and (311) correspond to high-carbon austenite, while the planes (110), (200), (211), and (310) refer to the acicular ferrite. Planes corresponding to the carbides, shown in the microstructural characterization, were not observed because of their low concentration in the CADIs samples. The volume fraction of high-carbon austenite was determined by using Equations (4)-(6) [25] and the XRD pattern results.

The volume fraction of high-carbon austenite, as a function of the austempering time, is shown in Figure 11. It is observed that high-carbon austenite increases for the shortest time, reaching a maximum value at $90 \mathrm{~min}$, and then starts to decrease to $120 \mathrm{~min}$ of austempering. The four CADIs evaluated show that the maximum value of high-carbon austenite is reached at $90 \mathrm{~min}$ of austempering. Therefore, the process window is located between 60 and 120 min for the austempering times evaluated; however, shorter times must be evaluated to more precisely determine a narrower process window. The results of the volume fraction of high-carbon austenite match with those reported in [43], where the volume fraction of high-carbon austenite was determined in the range from 9 to $15 \%$ for CADIs alloyed with $0.75 \mathrm{wt} \% \mathrm{Cr}$, heat-treated at $280{ }^{\circ} \mathrm{C}$. 


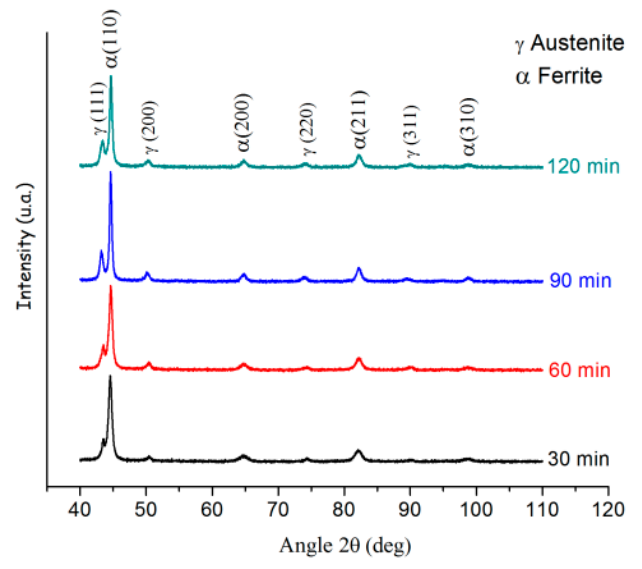

(a)

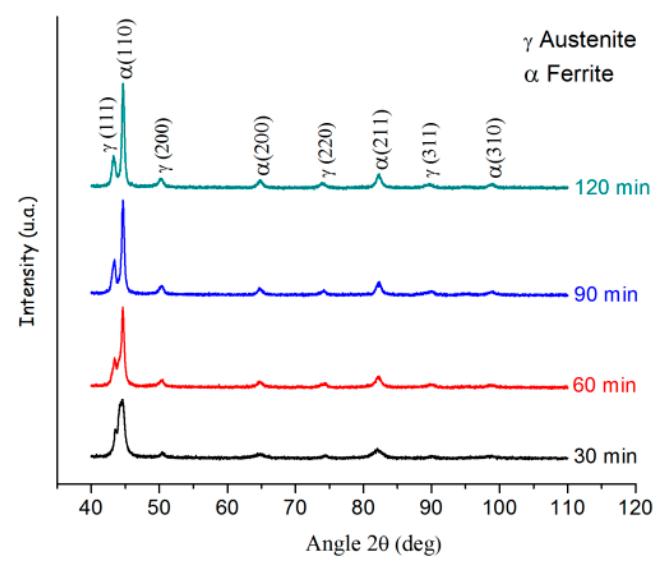

(c)

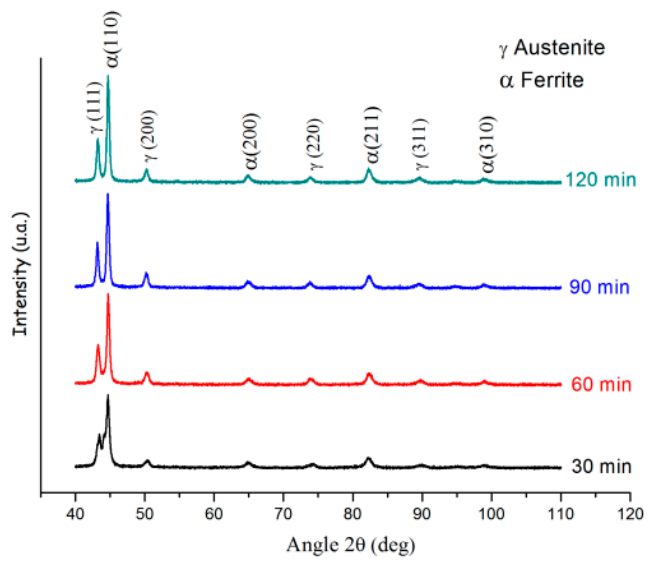

(b)

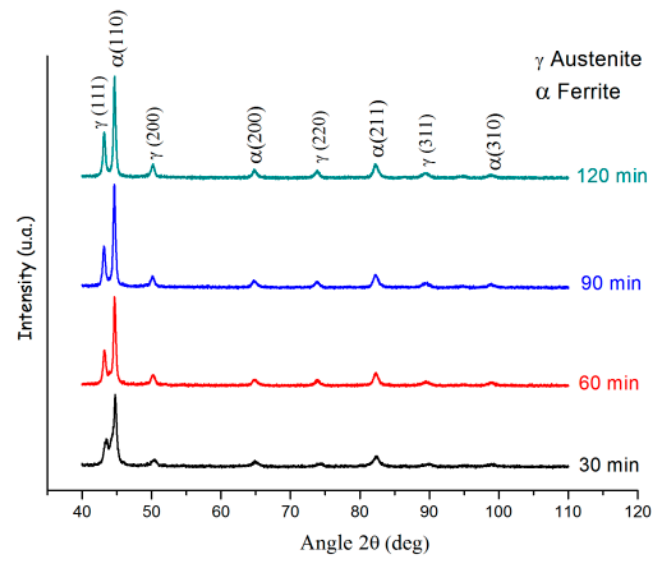

(d)

Figure 10. X-ray diffraction patterns of samples (a) CADI-0.2Cr-265, (b) CADI-0.2Cr-305, (c) CADI$0.4 \mathrm{Cr}-265$, and (d) CADI-0.4Cr-305.

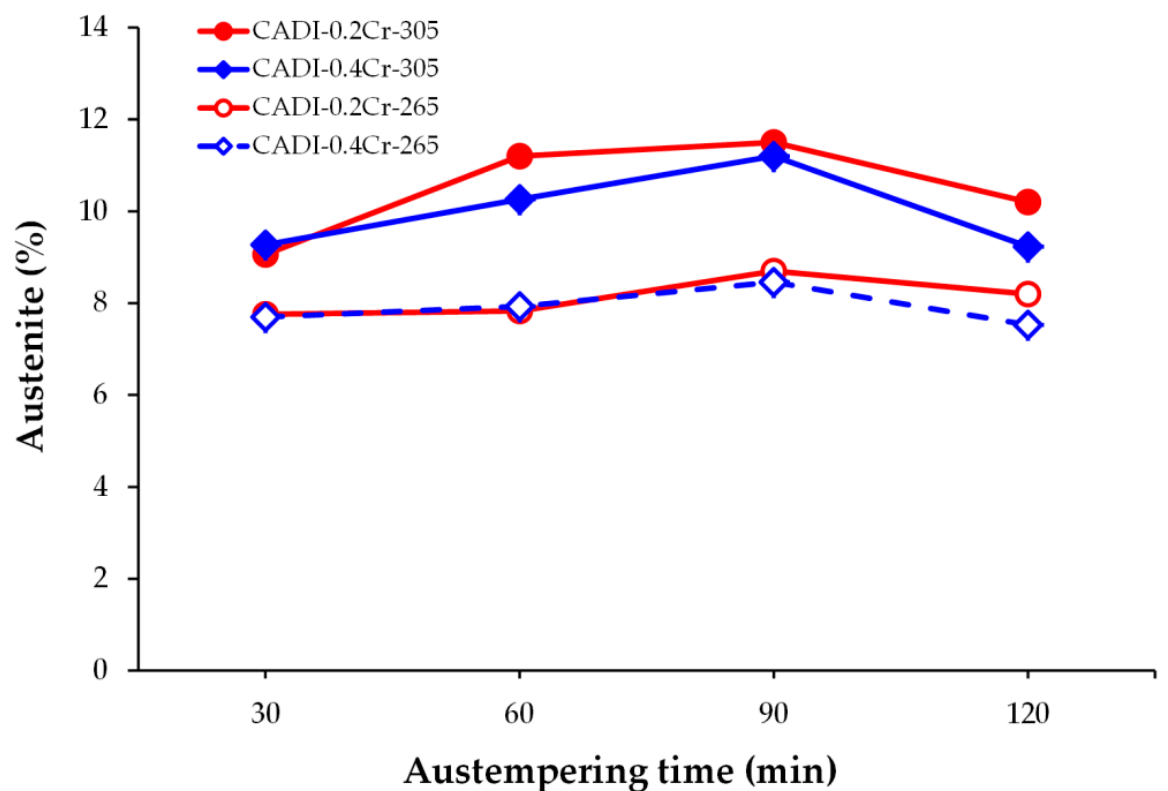

Figure 11. Effect of the austempering time and temperature on the high-carbon austenite formation for CADIs evaluated. 
It is also observed that the CADIs obtained at the high temperature of $305^{\circ} \mathrm{C}$ show a higher volume fraction of high-carbon austenite than the CADIs samples heat-treated at $265{ }^{\circ} \mathrm{C}$. This behavior is attributed to a low diffusion of carbon atoms during austempering at low temperatures. The unstable austenite ejects carbon atoms forming acicular ferrite, oversaturating a few amounts of austenite, due to its low diffusion, attributed to the low temperature of $265{ }^{\circ} \mathrm{C}$; as a result, little blocks of austenite can be oversaturated with carbon remaining stable at room temperature. When the austempering temperature is increased, the diffusion of carbon atoms increases, oversaturating more regions of austenite [36]. CADIs alloyed with $0.2 \mathrm{wt} \% \mathrm{Cr}$ obtained a higher volume fraction of highcarbon austenite than CADIs alloyed with $0.4 \mathrm{wt} \% \mathrm{Cr}$, and as a result of the increase of the volume fraction of carbides, the volume fraction of high-carbon austenite decreased [44]. In addition, the volume fraction of high-carbon austenite is also decreased when the nodularity is decreased [45].

\subsection{Mechanical Properties of DIs and CADIs}

Table 3 shows the mechanical properties of the standard camshaft iron and ductile irons alloyed with 0.2 and $0.4 \mathrm{wt} \% \mathrm{Cr}$.

Table 3. Mechanical properties of the ductile irons unalloyed and alloyed with 0.2 and $0.4 \% \mathrm{Cr}$.

\begin{tabular}{cccc}
\hline Mechanical Properties & DI-U & DI-0.2Cr & DI-0.4Cr \\
\hline Hardness (HRC) & $28 \pm 2.31$ & $29 \pm 3.02$ & $33 \pm 1.27$ \\
Tensile Strength (MPa) & $735 \pm 32$ & $750 \pm 28$ & $741 \pm 35$ \\
Elongation (\%) & $5.42 \pm 0.63$ & $4.44 \pm 0.56$ & $3.6 \pm 0.45$ \\
Impact Energy (J) & $9.3 \pm 1.41$ & $7.44 \pm 2.33$ & $4.85 \pm 1.93$ \\
Wear resistance $\left(\mathrm{mm}^{3}\right)$ & $1.25 \pm 0.18$ & $1.02 \pm 0.14$ & $0.939 \pm 0.23$ \\
\hline
\end{tabular}

\subsubsection{Rockwell C Hardness}

The average of Rockwell $\mathrm{C}$ hardness and its standard deviation for DIs (as-cast condition) and CADIs heat-treated to 265 and $305{ }^{\circ} \mathrm{C}$ for the austempering times of 30, 60, 90, and $120 \mathrm{~min}$ are shown in Table 4 . It is observed that the hardness values obtained after the austempering heat treatment are higher than those obtained for the as-cast condition. During austempering heat treatments, the softer phase pearlite, obtained in the as-cast condition, is transformed into harder phases as martensite, ausferrite, or bainite, obtaining an increase of the hardness measurements.

Table 4. Hardness (HRC), as a function of the austempering parameters for the CADIs evaluated.

\begin{tabular}{|c|c|c|c|c|c|}
\hline \multirow{2}{*}{$\begin{array}{c}\text { Sample } \\
\text { CADI-0.2Cr-265 }\end{array}$} & \multicolumn{5}{|c|}{ Hardness (HRC) } \\
\hline & $29 \pm 3.02$ & $57 \pm 0.63$ & $52 \pm 0.63$ & $47 \pm 0.11$ & $48 \pm 0.81$ \\
\hline CADI-0.4Cr-265 & $33 \pm 1.27$ & $60 \pm 0.51$ & $52 \pm 1.09$ & $49 \pm 0.51$ & $50 \pm 1.03$ \\
\hline CADI-0.2Cr-305 & $29 \pm 3.02$ & $48 \pm 0.52$ & $44 \pm 0.26$ & $42 \pm 0.83$ & $43 \pm 0.63$ \\
\hline CADI-0.4Cr-305 & $33 \pm 1.27$ & $51 \pm 0.13$ & $45 \pm 0.51$ & $43 \pm 0.40$ & $44 \pm 0.81$ \\
\hline Time (min) & As-cast & $30 \mathrm{~min}$ & $60 \mathrm{~min}$ & $90 \mathrm{~min}$ & $120 \mathrm{~min}$ \\
\hline
\end{tabular}

Figure 12 shows the hardness evolution as the austempering time was increased. The hardness behavior is directly related to the microstructural evolution, shown in Figures 6 and 7, as well as with the determination of the volume fraction of high-carbon austenite of Figure 11. 


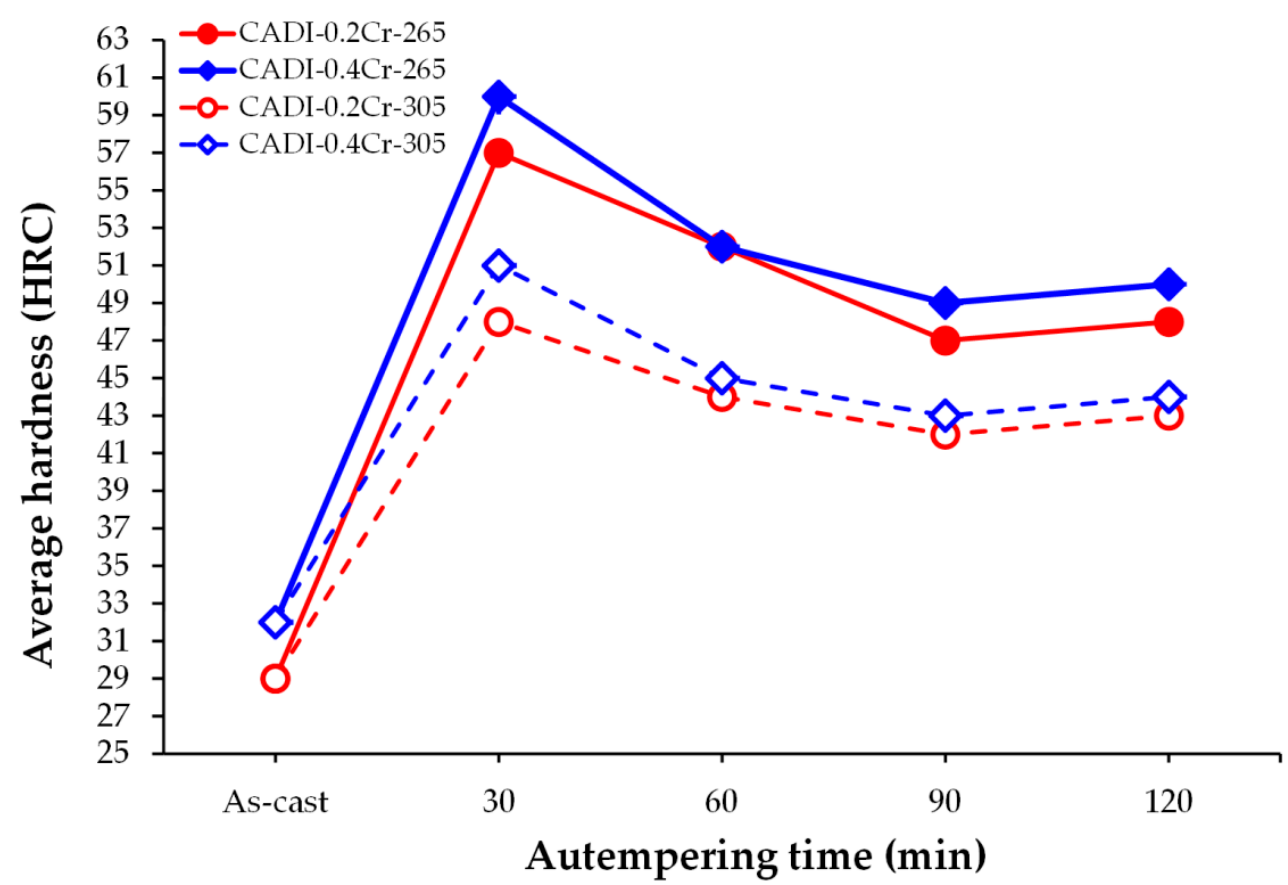

Figure 12. Effect of time and austempering temperature on Rockwell $\mathrm{C}$ hardness for CADIs camshaft.

It is observed from Figure 12 that hardness is sharply increased from the as-cast condition to the first austempering time, reaching a maximum; then, hardness values are decreased as the austempering time is increased, reaching the lowest value for the austempering time of $90 \mathrm{~min}$, followed by a slight hardness increase to the highest austempering time. This behavior is kept for the four CADIs evaluated. The lowest Rockwell C hardness values are found at $90 \mathrm{~min}$, where the highest volume fraction of high-carbon austenite (Figure 11) was obtained for the four CADIs evaluated. Therefore, the hardness behavior is directly related to the volume fraction of high-carbon austenite and match in the process window determination. Following the hardness trend obtained for the sample CADI-0.4Cr-305, at the as-cast condition, the microstructure is mainly constituted by pearlite, obtaining a hardness value of $33 \mathrm{HRC}$. After the austempering time of $30 \mathrm{~min}$, the microstructure is constituted mainly of martensite with a low amount of ausferrite, the higher amount of martensite allows obtaining the highest hardness value of $51 \mathrm{HRC}$ and the lowest value of $\mathrm{V} \gamma_{\mathrm{HC}}=9.27 \%$. For the austempering time of $60 \mathrm{~min}$, the microstructure changed to a mixture of a low amount of martensite, with an increase in the ausferrite amount; thus, the value of $\mathrm{V} \gamma_{\mathrm{HC}}$ increased to $10.26 \%$, while the hardness decreased to 45 HRC. When the austempering time is increased to $90 \mathrm{~min}$, the microstructure is constituted mainly by ausferrite with a small amount of martensite; this microstructure promotes the highest value of $\mathrm{V} \gamma_{\mathrm{HC}}=11.2 \%$ and lowest hardness value $(43 \mathrm{HRC})$. For the longest austempering time of $120 \mathrm{~min}$, the second stage of the process windows occurs, which means the beginning of the bainite formation; thus, the hardness slightly increased to $45 \mathrm{HRC}$, and the $\mathrm{V} \gamma_{\mathrm{HC}}$ decreased to $9.23 \%$. The hardness differences between CADIs heat-treated at two austempering temperatures are due to the different carbides amount, which aid to a hardness increase. CADIs containing the higher chromium amount present the higher volume fraction of carbide and, therefore, the higher hardness values. The Rockwell $C$ hardness obtained in this work fit with the results reported in [46], where CADIs alloyed with chromium, copper, and nickel to low silicon contents, austempered to $325^{\circ} \mathrm{C}$, were studied, obtaining hardness values in the range between 47 and $52 \mathrm{HRC}$.

\subsubsection{Tensile Test}

The results of yield and tensile strength are shown in Figure 13 for the CADIs produced. It is observed that the yield and tensile strength are remarkably increased from the as-cast 
to the austempered conditions for both chromium contents. The CADIs austempered to the lower temperature of $265^{\circ} \mathrm{C}$ showed higher tensile strength values than CADIs produced to $305^{\circ} \mathrm{C}$ for both chromium additions. The lower austempering temperature promoted a microstructure of fine ausferrite; this is a mixture of a high-volume fraction of ferrite with low amounts of high-carbon austenite. Finer phases provide a great barrier to the dislocation movement, causing an increase in the strength of the material $[36,47,48]$. The CADI-0.2Cr-265 reached the highest yield and tensile strength values of 902 and $1027 \mathrm{MPa}$, respectively, followed by the CADI-0.4Cr-265, with 811 and $930 \mathrm{MPa}$ for the yield and tensile strength, respectively. The CADIs austempered at $305^{\circ} \mathrm{C}$ showed similar tensile strength, in the range from 818 to $802 \mathrm{MPa}$, while the yield strength was in the range from 697 to 686 for the chromium additions of 0.2 and $0.4 \mathrm{wt} \% \mathrm{Cr}$, respectively. The tensile strength results obtained in this work were slightly higher than those obtained for ADIs with the same chromium additions heat-treated to $350{ }^{\circ} \mathrm{C}$ [12]. The elongation was in the range expected for this material (between 3.5 and $4.5 \%$ ); the highest elongation was obtained for the CADIs, with the lowest chromium content, which presents the lowest carbide amount.

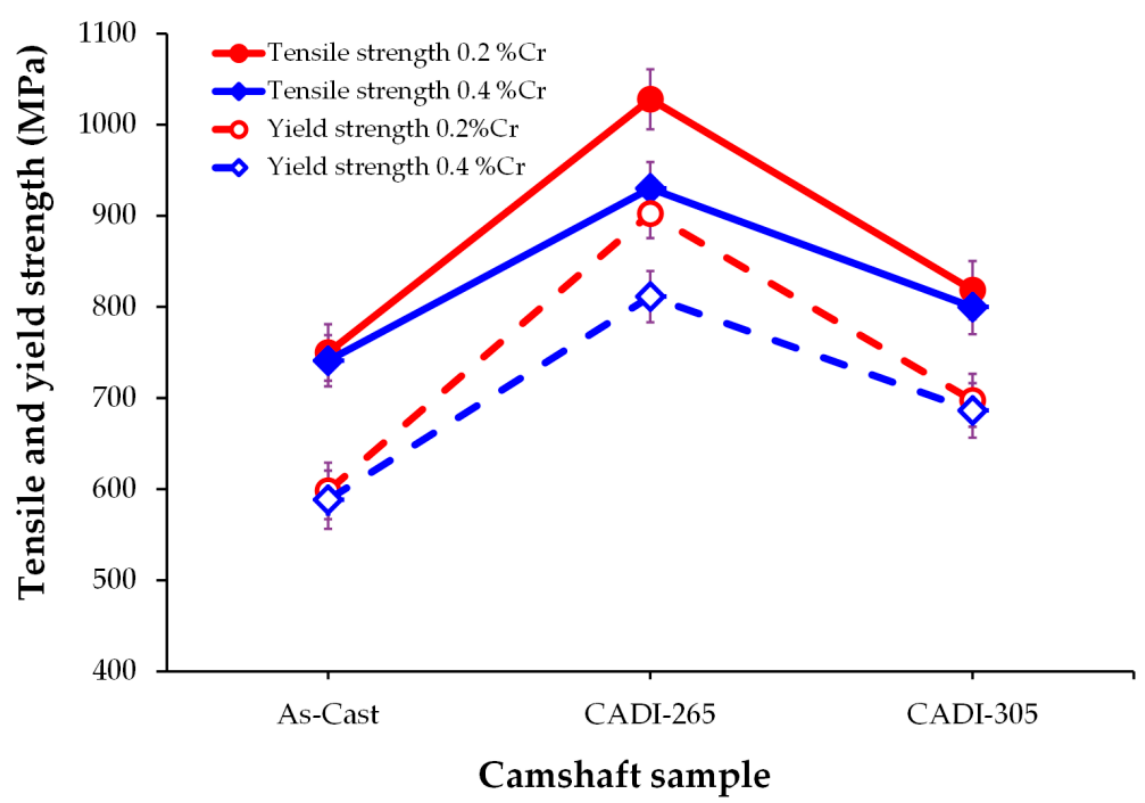

Figure 13. Influence of chromium content and austempering temperature on yield and tensile strength of the CADIs produced.

\subsubsection{Charpy Impact Energy}

The effects of the chromium addition and austempering temperature on the Charpy impact energy are shown in Figure 14. It is evident that the Charpy impact energy is higher in the CADIs produced than in the as-cast condition; this behavior is attributed to the ausferrite matrix and volume fraction of carbides presented in each sample. In both cases, the Charpy impact energy increased linearly from the as-cast condition to the CADIs produced for the austempered temperature evaluated. The ductile irons and CADIs containing $0.4 \mathrm{wt} \% \mathrm{Cr}$ showed the lowest impact energy values, due to a higher volume fraction of carbides than DI and CADIs containing $0.2 \mathrm{wt} \% \mathrm{Cr}$. The carbides interrupt the continuity of the matrix, acting as crack initiation sites $[30,49]$. On the other hand, CADIs heat treated to the higher austempered temperature showed the higher impact energy values; this behavior is explained by the presence of a higher volume fraction of high-carbon austenite, which improves the fracture toughness of the CADIs [50]. The results fit with those reported for impact energy measurements in CADIs austempered in the range from 210 to $320^{\circ} \mathrm{C}$, obtaining impact energy values in the range of 16 to $24 \mathrm{~J}$ [13]. 


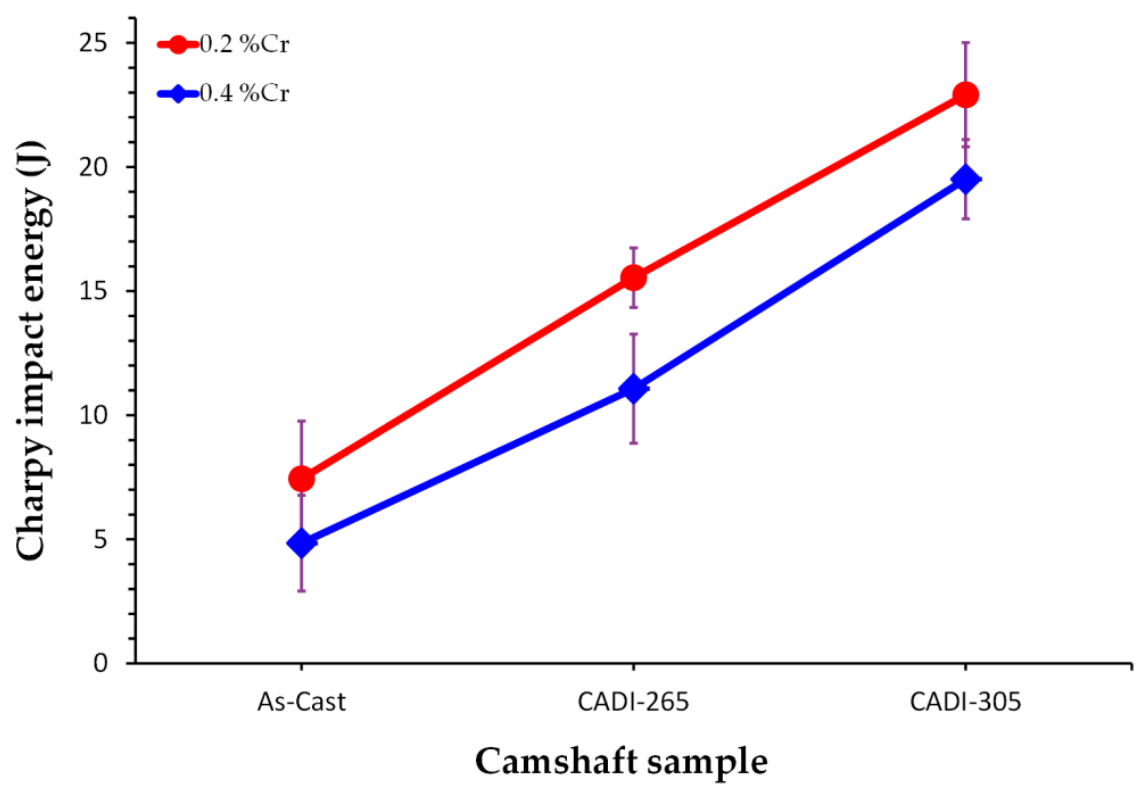

Figure 14. Influence of chromium content and austempering temperature on the impact energy for the CADIs evaluated.

\subsubsection{Wear Resistance}

The block-on-ring wear test was carried out on DIs and CADIs samples; the scar width was measured and, by using Equation (7), the volume loss of material removed by the abrasion of the sample with the metal ring was determined. The wear scars of the DIs and CADIs are shown in Figure A4, from Appendix A, while the volume loss of each material is observed in Figure 15. As expected, the as-cast condition microstructure is constituted mainly of pearlite, which is a softer phase, if it is compared with the ausferrite and martensite microstructures obtained for CADIs. As can be observed in Figure 12 and Table 4 , there is a remarkable hardness difference in both materials; therefore, the volume loss of material is higher for the as-cast condition than the CADIs, showing a lower wear resistance [42]. In addition, the increase of the carbide amount reinforces the metallic matrix, due to its high hardness, increasing the wear resistance of the material [31]. It is observed that the austempering temperature affects the wear resistance of the CADIs evaluated. The higher wear resistance values are obtained for the CADIs heat-treated at 265 ${ }^{\circ} \mathrm{C}$ because of the higher volume fraction of ferrite acicular, presented in the fine ausferritic matrix; this condition is beneficial to improve wear resistance [51]. On the contrary, higher austempering temperatures increase the volume fraction of high-carbon austenite and the ausferrite is coarser; hence, the wear resistance is decreased [52].

Table 5 shows a summary of the mechanical properties achieved for the carbidic austempered ductile irons, alloyed with 0.2 and $0.4 \mathrm{wt} \% \mathrm{Cr}$, and obtained after applying an austempering heat treatment at 265 and $305^{\circ} \mathrm{C}$.

Table 5. Mechanical properties of the CADIs evaluated.

\begin{tabular}{cccccc}
\hline Sample & $\begin{array}{c}\boldsymbol{\sigma}_{\mathbf{o}} \\
\mathbf{M P a}\end{array}$ & $\boldsymbol{\sigma}_{\text {UTS }} \mathbf{( M P a )}$ & Hardness (HRC) & Impact Energy (J) & $\begin{array}{c}\text { Volume Loss } \\
\left(\mathbf{m m}^{\mathbf{3}}\right)\end{array}$ \\
\hline CADI-0.2Cr-265 & 902 & 1027 & 47 & 15.54 & 0.522 \\
CADI-0.4Cr-265 & 811 & 920 & 49 & 11.07 & 0.316 \\
CADI-0.2Cr-305 & 697 & 818 & 42 & 22.91 & 0.569 \\
CADI-0.4Cr-305 & 686 & 800 & 43 & 19.51 & 0.42 \\
\hline
\end{tabular}




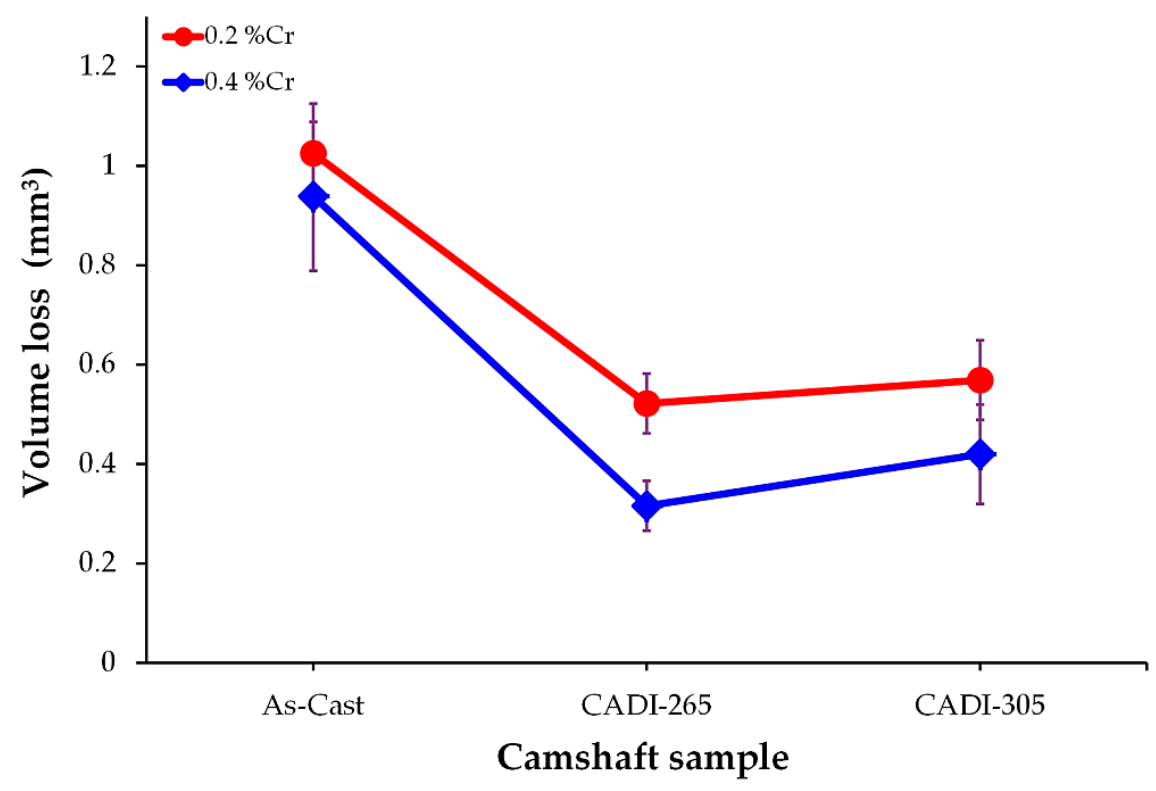

Figure 15. Effect of the austempering temperature and chromium content in the wear resistance for the CADIs evaluated.

As can be observed, the sample CADI- $0.4 \mathrm{Cr}-265$ presents the higher hardness and lowest volume loss of material, which indicates a high wear resistance. However, as expected for this type of material, the toughness is affected, as noted in the impact energy value obtained by the Charpy impact test. Camshaft, produced with the CADI alloyed with $0.4 \mathrm{wt} \% \mathrm{Cr}$, heat-treated at $265^{\circ} \mathrm{C}$, could be considered to dabble in the market of the chilled gray cast iron, where a minimum hardness of $45 \mathrm{HRC}$ is requested in the lobe [53]. It must be noted that the sample CADI- $0.2 \mathrm{Cr}$-265 exhibits a high strength, with a slightly higher toughness; however, the hardness and wear resistance slightly decrease in the CADI- $0.4 \mathrm{Cr}$ 265 sample. It is possible to increase the hardness and wear resistance of the camshafts by increasing the amount of chromium added; however, the strong carbide forming tendency of the chromium could affect the further mechanical operations in the camshaft production. Therefore, more trials are required to obtain an adequate relationship between mechanical properties and machining steps in camshaft production.

\section{Conclusions}

In this work, two carbidic austempered ductile irons were produced from ductile irons low alloyed with 0.2 and $0.4 \mathrm{wt} \% \mathrm{Cr}$, which were heat-treated to 265 and $305{ }^{\circ} \mathrm{C}$ for camshaft production. A microstructural and mechanical evaluation was carried out on the DIs and CADIs produced. The results obtained can be summarized as follows:

1. The amounts of copper, manganese, and chromium added to the cast alloys allow for obtaining graphite nodules in a matrix, constituted mainly of pearlite and carbides. The highest carbide formation is located at the middle of the lobes, due to the inverse chill effect, where the carbide-forming elements ( $\mathrm{Mn}$ and $\mathrm{Cr}$ ) increase their concentration in the last liquid to solidify.

2. The volume fraction of carbides was increased from 0.65 to $2.87 \%$, when the chromium amount was increased from 0.2 to $0.4 \mathrm{wt} \%$, and they were not dissolved during the austenitizing heat treatment.

3. A microstructure constituted by fine ausferrite and carbides was obtained for both CADIs austempered to $265^{\circ} \mathrm{C}$, while coarse ausferrite and carbides were obtained for CADIs heat-treated to $305^{\circ} \mathrm{C}$.

4. The process window was obtained by hardness measurements and the volume fraction of high-carbon austenite determination. The PW occurs in the range from 90 to $120 \mathrm{~min}$ of austempering heat treatment. The highest $\mathrm{V} \gamma_{\mathrm{HC}}$ was obtained for the austempering 
time of $90 \mathrm{~min}$ for both CADIs alloyed with 0.2 and $0.4 \mathrm{wt} \% \mathrm{Cr}$, as well as for the highest austempering temperature.

5. The desired mechanical properties of high hardness and wear resistance for a CADI were achieved for the higher chromium content, where the hardness (49 HRC) and wear resistance $\left(0.316 \mathrm{~mm}^{3}\right)$ were the highest. The sample CADI-0.4Cr-265 meets these requirements. However, the toughness $(11 \mathrm{~J})$ and strength $(920 \mathrm{MPa})$ of the camshaft were decreased.

Author Contributions: Data curation, E.C.G. and A.M.H.; formal analysis, E.C.G. and A.C.R.; funding acquisition, J.T.R.; investigation, E.C.G., A.C.R., J.F.C.A. and A.M.H.; methodology, E.C.G., A.C.R., J.F.C.A., J.T.R. and A.M.H.; project administration, J.T.R.; supervision, J.T.R.; validation, A.C.R. and J.T.R.; visualization, A.C.R. and A.M.H.; writing—original draft, E.C.G.; writing-review and editing, A.C.R. and E.C.G. All authors have read and agreed to the published version of the manuscript.

Funding: This research received no external funding.

Informed Consent Statement: Not applicable.

Data Availability Statement: No additional data.

Acknowledgments: The authors wish to thank the enterprise ARBOMEX S.A. de C.V. for the facilities given for the trial's development. A. Cruz and E. Colin wish to thank Institutions CONACyT, SNI, COFAA and SIP-Instituto Politécnico Nacional for their permanent assistance to the Process Metallurgy Group at ESIQIE-Metallurgy and Materials Department.

Conflicts of Interest: The authors declare no conflict of interest.

\section{Appendix A}
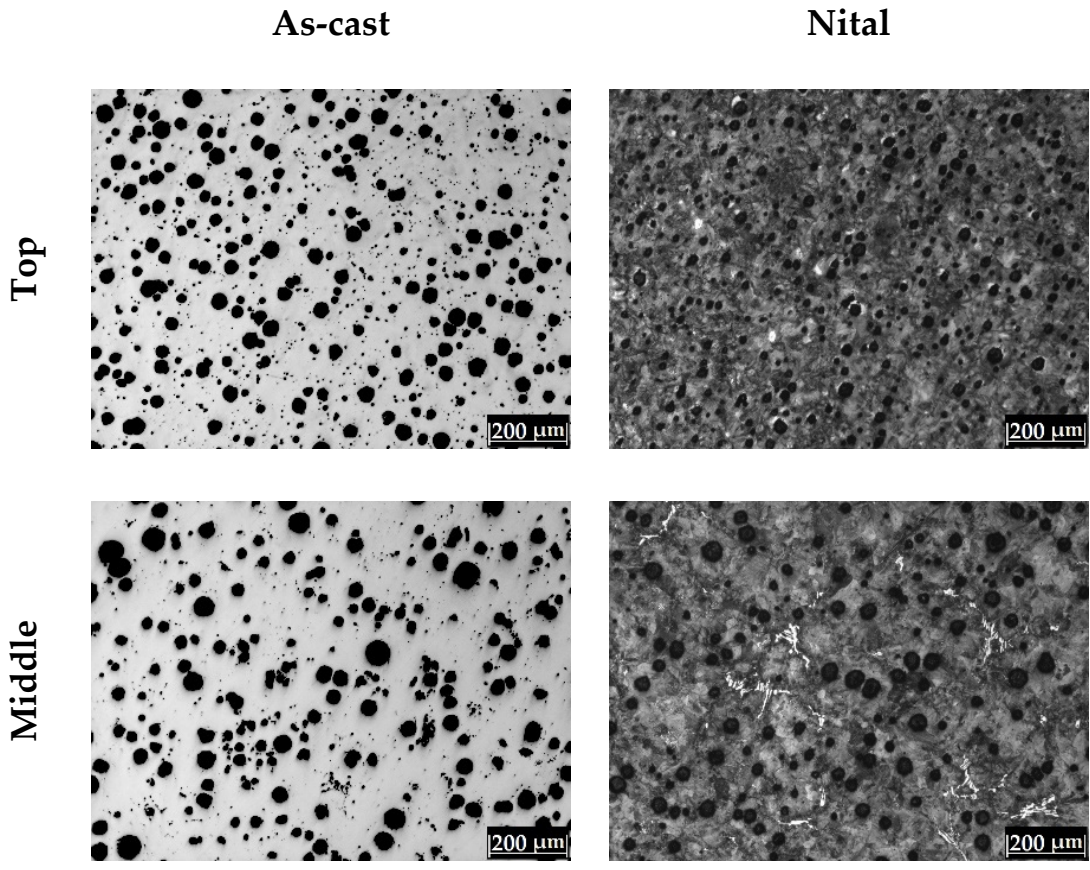

Ammonium persulfate
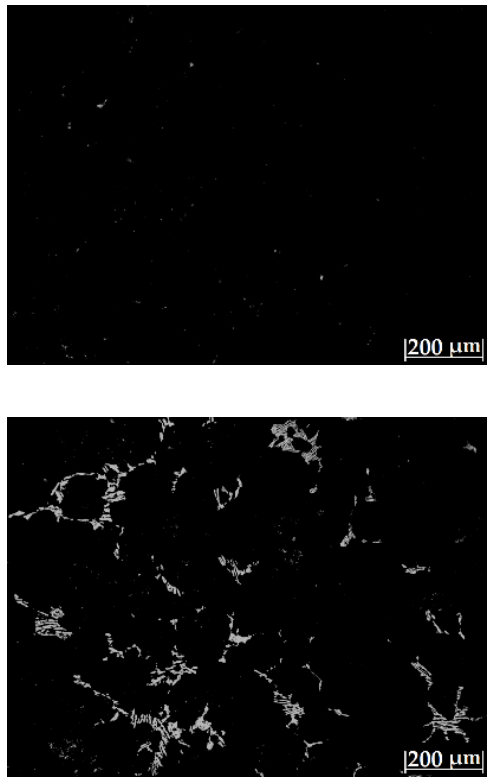

Figure A1. Cont. 


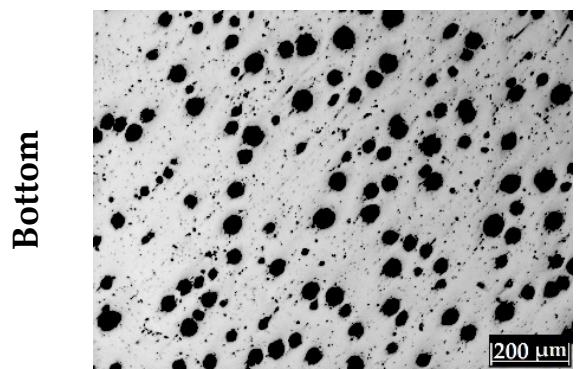

(a)

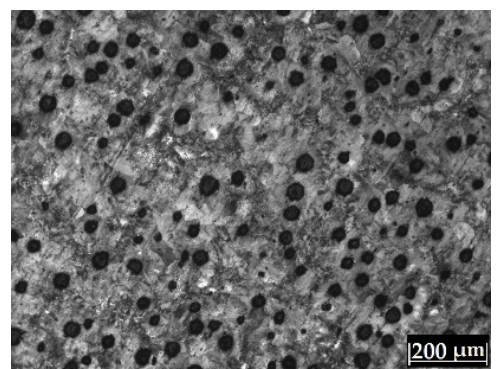

(b)

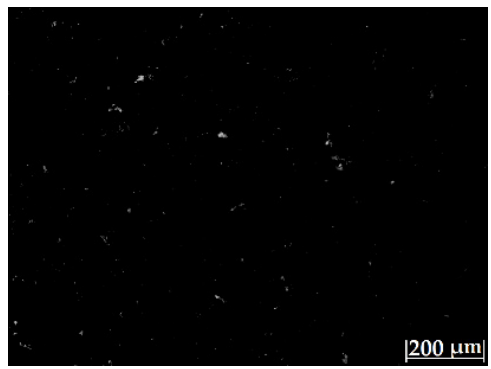

(c)

Figure A1. Microstructure of DI-0.2Cr sample for the top, middle, and bottom zones for (a) as-cast, (b) etched with nital, and (c) etched with ammonium persulfate conditions.

Top
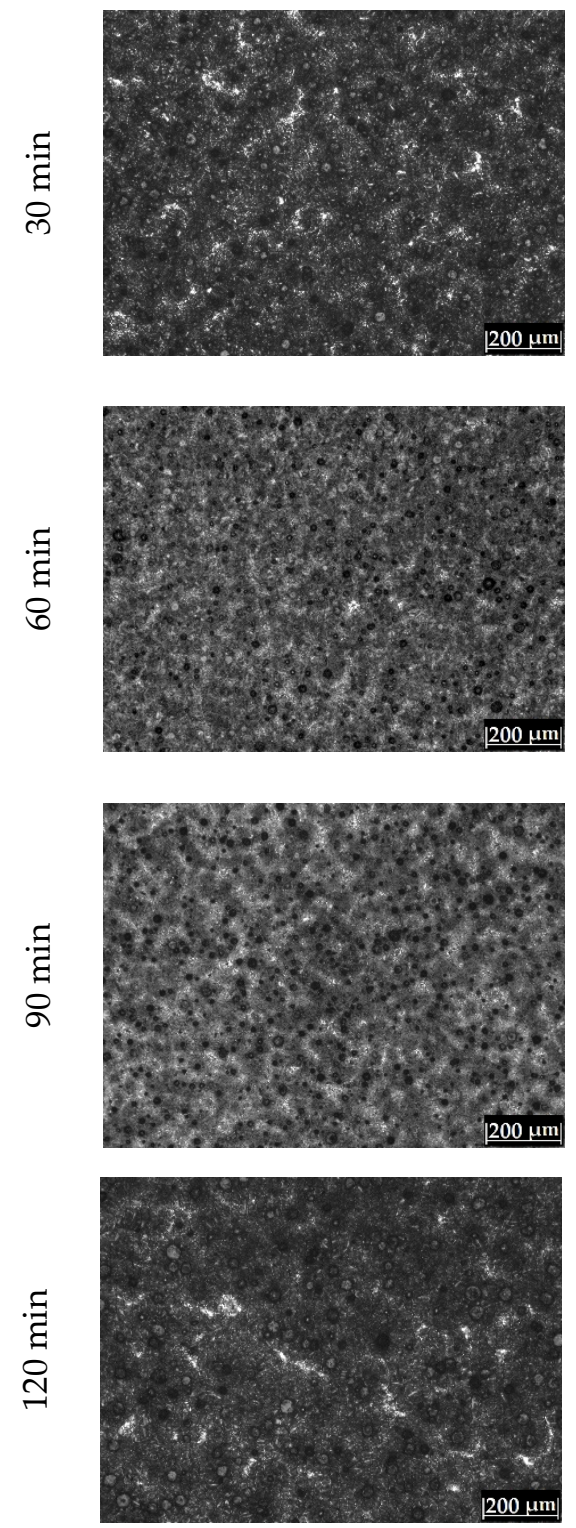

Middle
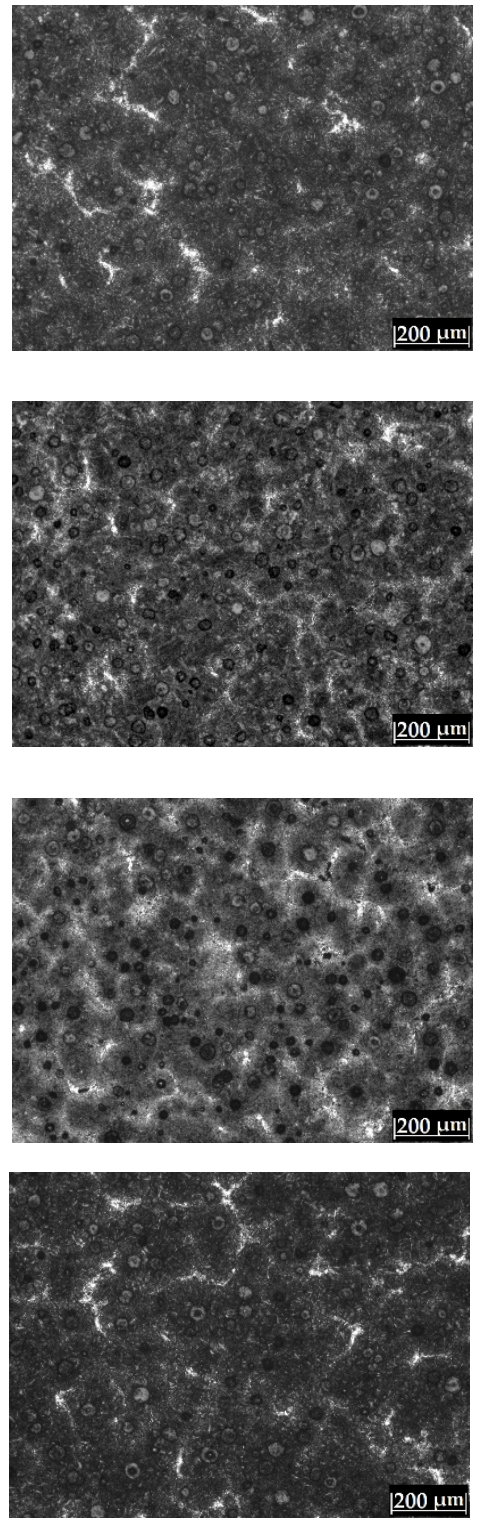

Bottom
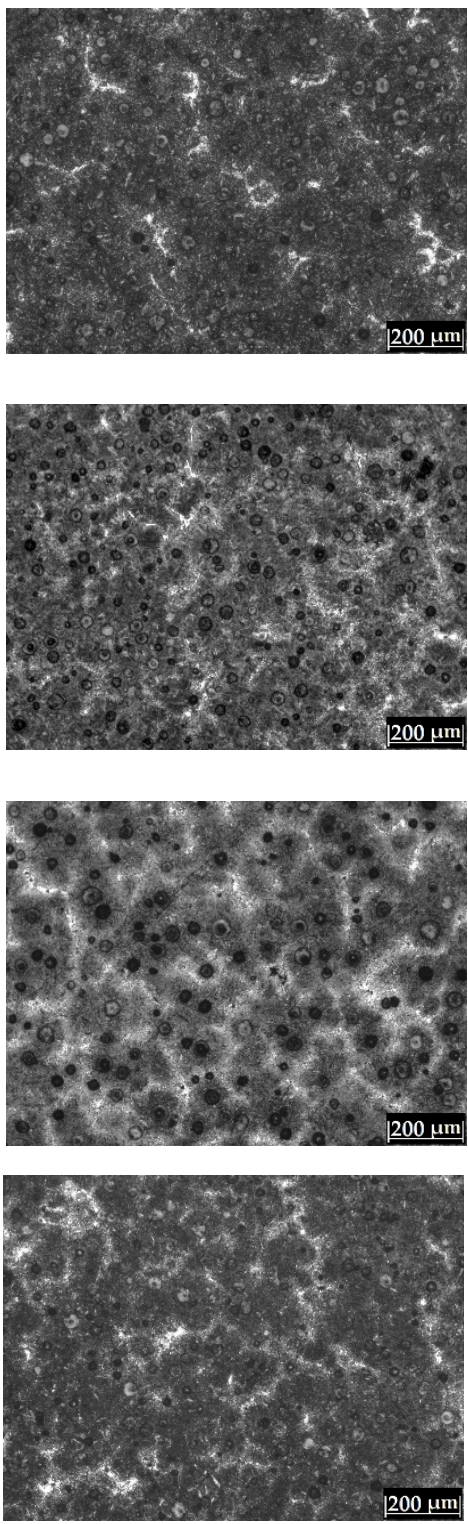

Figure A2. Microstructural evolution for the CADI-0.2Cr-265 sample at the austempering times of 30, 60,90 , and $120 \mathrm{~min}$ for the three regions analyzed. 
Top
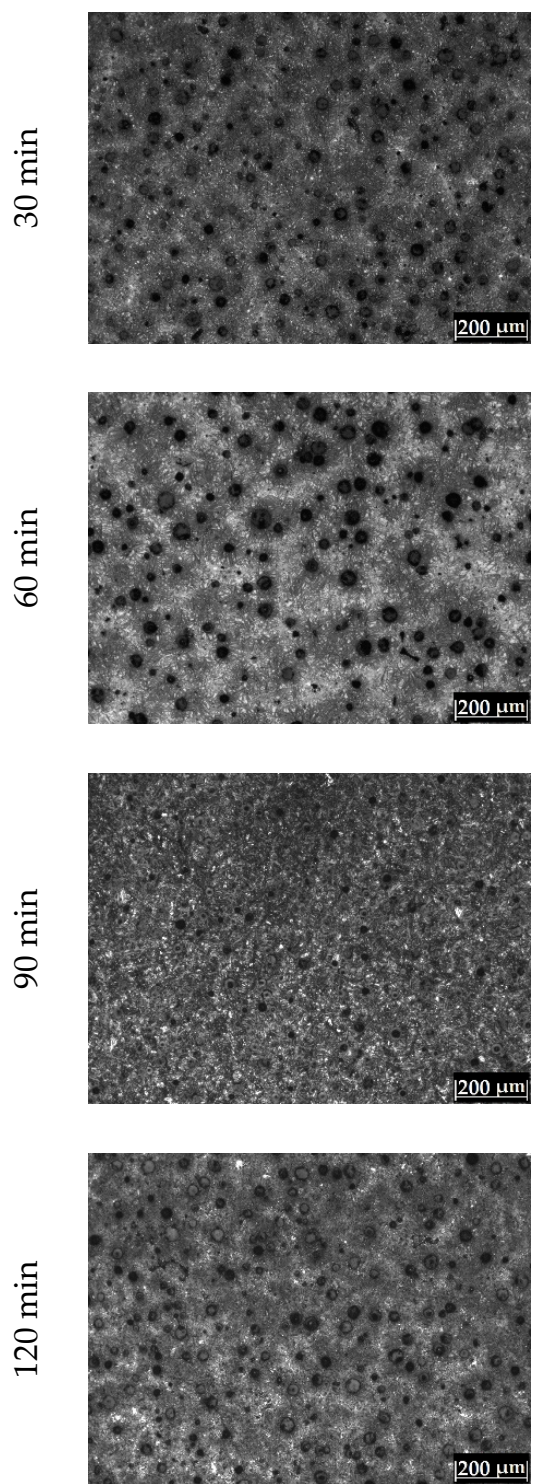

Middle
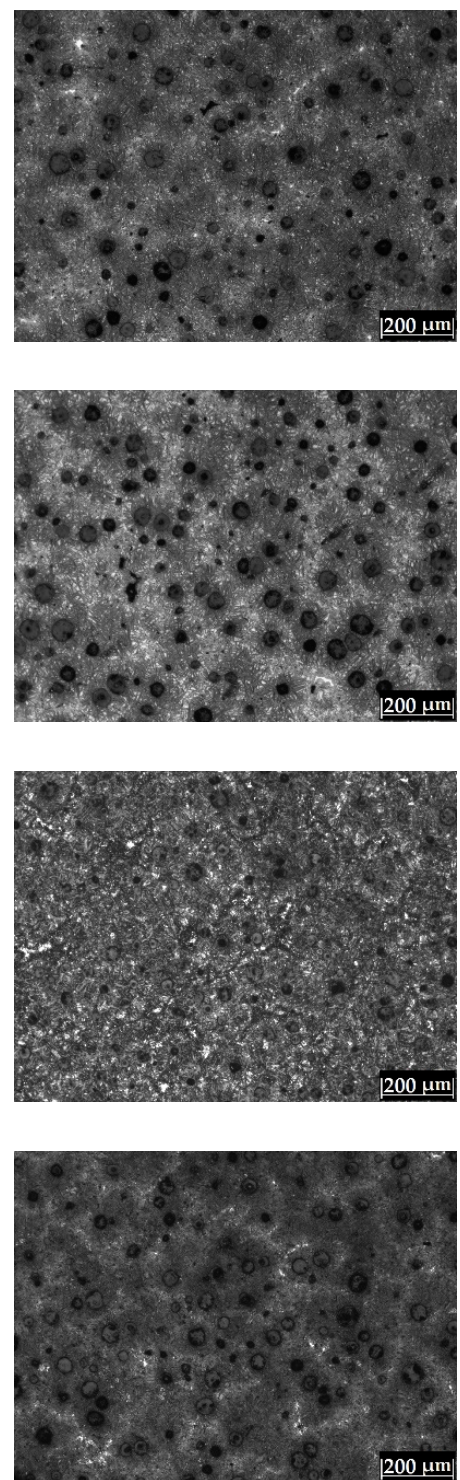

Bottom
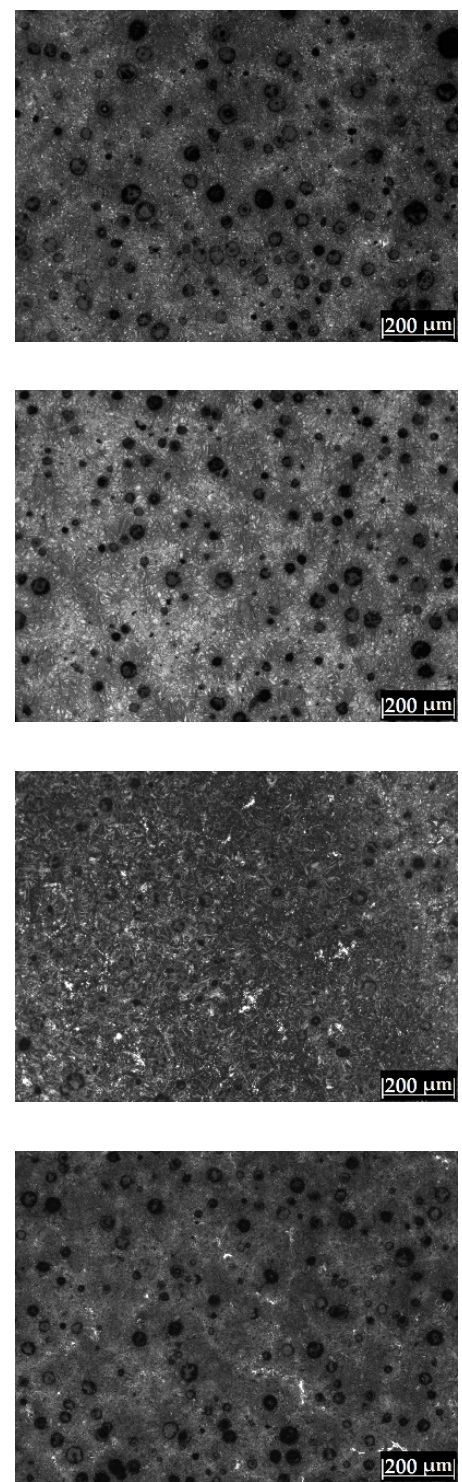

Figure A3. Microstructural evolution for the CADI-0.2Cr-305 sample at the austempering times of 30, 60,90 , and $120 \mathrm{~min}$ for the three regions analyzed.

$0.2 \mathrm{wt} \% \mathrm{Cr}$

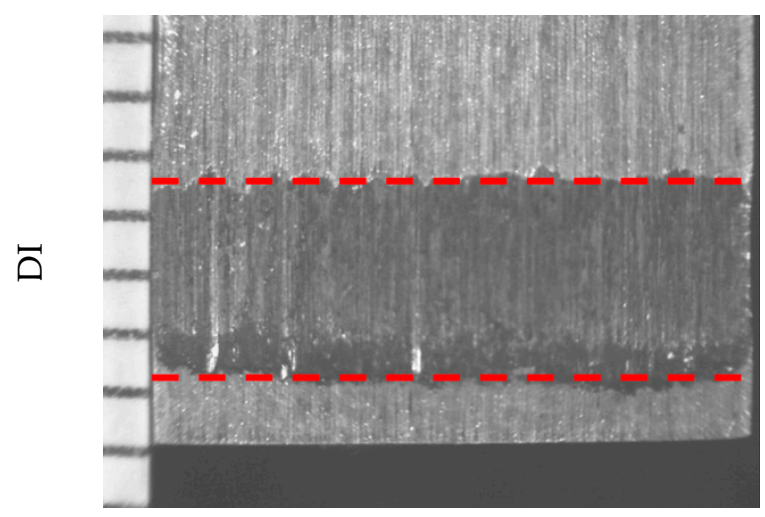

$0.4 \mathrm{wt} \% \mathrm{Cr}$

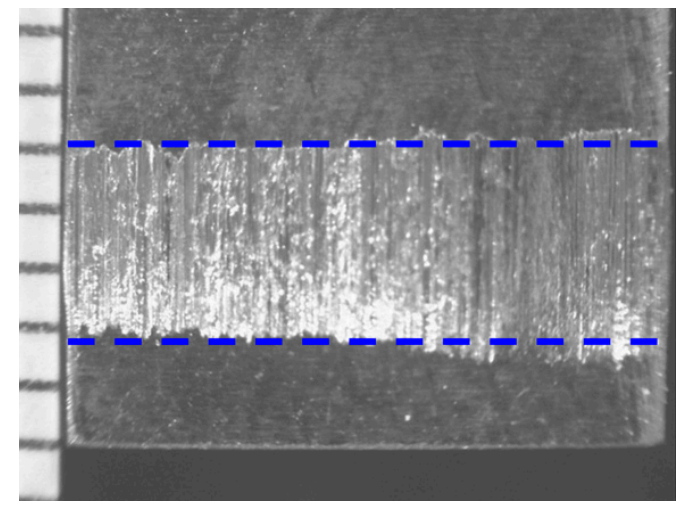

Figure A4. Cont. 

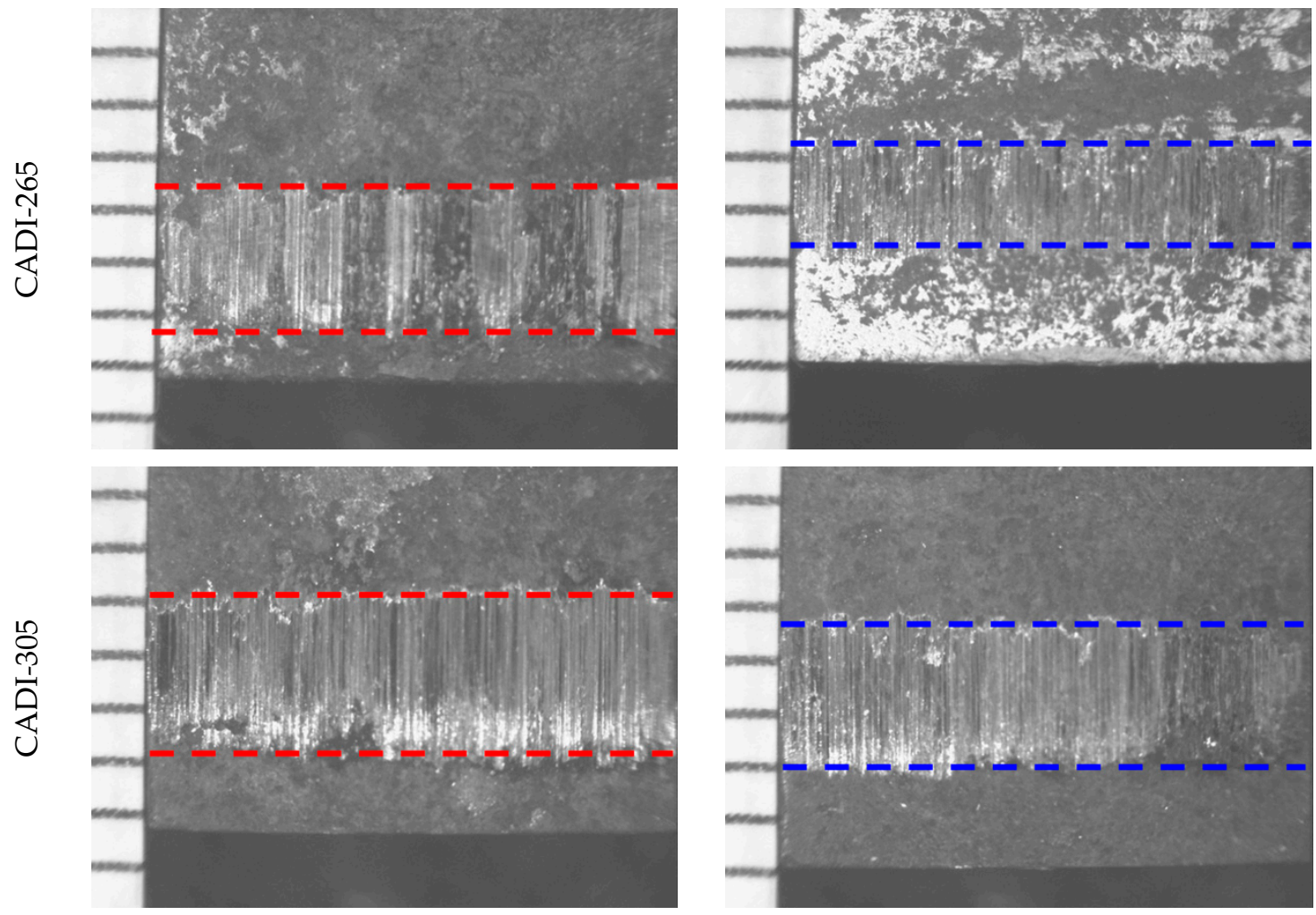

Figure A4. Wear scars samples for DI and CADI alloyed with 0.2 and $0.4 \%$ Cr, austempered at 265 and 305 for $90 \mathrm{~min}$.

\section{References}

1. Wang, B.; Barber, G.C.; Tao, C.; Sun, X.; Ran, X. Characteristics of tempering response of austempered ductile iron. J. Mater. Technol. 2018, 7, 198-202. [CrossRef]

2. Samaddar, S.; Das, T.; Chowdhury, A.K.; Singh, M. Manufacturing of engineering components with austempered ductile iron-A review. Mater. Today Proc. 2018, 5, 25615-25624. [CrossRef]

3. Gawhare, S.; Harne, M.; Patil, S. Effect of chemical composition and austempering temperature on properties of CADI. Int. J. Adv. Tech. Eng. Sci. 2015, 3, 184-193.

4. Peng, Y.-C.; Jin, H.-J.; Liu, J.-H.; Li, G.-L. Effect of boron on the microstructure and mechanical properties of carbidic austempered ductile iron. Mater. Sci. Eng. A 2011, 529, 321-325. [CrossRef]

5. Patil, S.A.; Pathak, S.U.; Likhite, A. Development and wear analysis of carbidic austempered ductile iron (CADI). Int. J. Innov. Res. Sci. Eng. Technol. 2014, 3, 9652-9657.

6. Prasad, R.P.; Putatunda, S.K. Investigations on the fracture toughness of austempered ductile irons austenitized at different temperatures. Mater. Sci. Eng. A 2003, 349, 136-149.

7. Yescas, M.A.; Bhadeshia, H.K.D.H. Model for the maximum fraction of retained austenite in austempered ductile iron. Mater. Sci. Eng. A 2002, 333, 60-66. [CrossRef]

8. Swain, S.K.; Panda, R.K.; Mishra, J.P.; Sen, S. Phase investigation of austempered ductile iron. Orissa J. Phys. 2012, 19 , 73-80.

9. Pereloma, E.V.; Anderson, C.S. Microstructure and properties of austempered ductile iron subjected to single and two step processing. Mater. Sci. Technol. 2006, 22, 1112-1118. [CrossRef]

10. Gazda, A. Analysis of decomposition processes of ausferrite in copper-nickel austempered ductile iron. J. Therm. Anal. Calorim. 2010, 102, 923-930. [CrossRef]

11. Muralidhara, A.L.; Rao, P.P. Austempering of Nickel-Chromium Alloyed Ductile Irons. AFS Trans. 1988, 94, 387-396.

12. Bedolla, J.A.; Hernández, H.R.A.; Vapeani, G.F.; Mejia, I. The role of chromium during austempering of ductile iron. Metall. Res. Technol. 2020, 117, 1-10.

13. Liu, J.; Li, G.; Zhao, X.; Hao, X.; Zhang, J. Effect of austempering on the microstructure and properties of carbidic austempered ductile iron. Adv. Mater. Res. 2011, 284-286, 1085-1088. [CrossRef]

14. Bayrakceken, H.; Ucun, I.; Tasgetiren, S. Fracture analysis of a camshaft made from nodular cast iron. Eng. Fail. Anal. 2006, 13, 1240-1245. [CrossRef]

15. Bereteu, L.; Crâştiu, I.; Nyaguly, E.; Simoiu, D. Investigation of a camshaft repaired by welding using the vibration signal analysis. Adv. Mater. Res. 2015, 1111, 199-204. [CrossRef] 
16. Chernyshev, A.N.; Kaplina, I.N.; Serapin, M.I. Surface hardening with remelting of functional surfaces of cast iron camshafts. Met. Sci. Heat Treat. 1996, 38, 440-442. [CrossRef]

17. Mi, G.; He, B.; Wang, Y. Effect of temperature and inoculation on the structure property of chilled cast iron camshaft. Adv. Mater. Res. 2011, 152-153, 154-158. [CrossRef]

18. Kumruoğlu, L.C. Mechanical and microstructure properties of chilled cast iron camshaft: Experimental and computer aided evaluation. Mater. Des. 2009, 30, 927-938. [CrossRef]

19. Lasota, I.; Protsenko, V.; Matyushkin, A.; Kuznetsov, M.; Gook, S. Laser surface hardening of engine camshaft cams. Mater. Today Proc. 2020, 30, 1-5. [CrossRef]

20. Ogata, P.E.; Dos Santos Filho, D.; Okazaki, L.; Nishikawa, L.P.; Goldenstein, H. A study on the camshaft lobe microstructure obtained by different processing. In Proceedings of the 21st SAE Brasil International Congress and Exhibition, São Paulo, Brazil, 2-4 October 2012.

21. Karaca, B.; Şimşir, M. The effects of austempering and induction hardening on the wear properties of camshaft made of ductile cast iron. Acta Phys. Pol. 2017, 131, 448-452. [CrossRef]

22. Colin, G.E.; Cruz, R.A.; Reyes, C.G.; Téllez, R.J.; Magaña, H.A. Microstructural and mechanical assessment of camshafts produced by ductile cast iron low alloyed with vanadium. Metals 2021, 11, 146. [CrossRef]

23. Colin, G.E.; Cruz, R.A.; Reyes, C.G.; Chávez, A.J.F.; Téllez, R.J.; Magaña, H.A. Heat treatment evaluation for the camshats production of ADI low alloyed with vanadium. Metals 2021, 11, 1036. [CrossRef]

24. Ruxunda, R.E.; Stefanescu, D.M.; Pinwonka, T.S. Microstructure characterization of ductile thin-wall iron castings. AFS Trans. 2002, 110, 1131-1147.

25. Miller, R.L. A rapid method for the determination of retained austenite. Trans. ASM 1964, 57, 892-899.

26. Stefanescu, D.M. Ductile Iron, Control of the Composition of Ductile Iron; Handbook Volume 15 Castings; ASM International: Almere, The Netherlands, 1998; p. 1408.

27. Bayati, H.; Elliott, R. Austempering process in high manganese alloyed ductile cast iron. Mater. Sci. Technol. 1995, 11, 118-129. [CrossRef]

28. Sadighzadeh, B.A. Effect of alloying elements on austempered ductile iron (ADI) properties and its process: Review. China Foundry 2015, 12, 54-70

29. Colin, G.E.; Cruz, R.A.; Reyes, C.G.; Romero, S.J.A.; Sanchez, A.R.G.; Hernández, C.M. Influence of nickel addition and casting modulus on the properties of hypo-eutectic ductile cast iron. J. Min. Metall. Sect. B Metall. 2019, 55, 115-124.

30. Resvani, M.; Harding, R.A.; Camplell, J. The effect of vanadium in as-cast ductile iron. Int. J. Cast Met. Res. 1997, 10, 1-15. [CrossRef]

31. Laino, S.; Sikora, J.A.; Dommarco, R.C. Development of wear resistant carbidic austempered ductile iron. Wear 2008, 265, 1-7. [CrossRef]

32. Yang, J.; Putatunda, S.K. Improvement in strength and toughness of austempered ductile cast iron by a novel two-step austempering process. Mater. Des. 2004, 25, 219-230. [CrossRef]

33. Akbarzadeh, C.E.; Iranipour, N.; Yazdani, S. Effect of nodule count and austempering heat treatment on segregation behavior of alloying elements in ductile cast iron. China Foundry 2016, 13, 217-222. [CrossRef]

34. Jahangiri, M.R.; Nili, A.M.; Farhangi, H. Enhancement of fatigue properties of ductile irons by successive austempering heat treatment. J. Mater. Eng. Perform. 2011, 20, 1642-1647. [CrossRef]

35. Cekic, O.E.; Sidjanin, L.; Rajnovic, D.; Rajnovic, D.; Balos, S. Austempering kinetics of Cu-Ni alloyed austempered Ductile Iron Met. Mater. Int. 2014, 20, 1131-1138. [CrossRef]

36. Putatunda, S.K.; Gadicherla, P.K. Effect of austempering time on mechanical properties of a low manganese austempered ductile iron. J. Mater. Eng. Perform. 2000, 9, 193-203. [CrossRef]

37. Wang, B.; Barber, G.C.; Qiu, F.; Zou, Q.; Yang, H. A review: Phase transformation and wear mechanisms of single-step and dual-step austempered ductile irons. J. Mater. Res. Technol. 2019, 9, 1054-1069. [CrossRef]

38. Han, J.M.; Zou, Q.; Barber, G.C.; Nasir, T.; Northwood, D.O.; Sun, X.C.; Seaton, P. Study of the effects of austempering temperature and time on scuffing behavior of austempered Ni-Mo-Cu ductile iron. Wear 2012, 290-291, 99-105. [CrossRef]

39. Han, C.F.; Sun, Y.F.; Wu, Y.; Ma, Y.H. Effects of Vanadium and Austempering Temperature on Microstructure and Properties of CADI. Metallogr. Microstruct. Anal. 2015, 4, 135-145. [CrossRef]

40. Han, C.F.; Wang, Q.Q.; Sun, Y.F.; Li, J. Effects of Molybdenum on the Wear Resistance and Corrosion Resistance of Carbidic Austempered Ductile Iron. Metallogr. Microstruct. Anal. 2015, 4, 298-304. [CrossRef]

41. Colin, G.E.; Cruz, R.A.; Romero, S.J.A.; Sánchez, A.R.G.; Gutiérrez, P.V.H.; Reyes, C.G. Nodule count effect on microstructure and mechanical properties of hypo-eutectic ADI alloyed with nickel. J. Min. Metall. Sect. B Metall. 2021, 57, 115-124. [CrossRef]

42. Minkoff, I. The Physical Metallurgy of Cast Iron; John Wiley and Sons: Salisbury, UK, 1983; p. 183.

43. Sun, X.; Wang, Y.; Li, D.Y.; Wang, G. Modification of carbidic austempered ductile iron with nano ceria for improved mechanical properties and abrasive wear resistance. Wear 2013, 301, 116-121. [CrossRef]

44. Bakhshinezhad, H.; Honarbakhshraouf, A.; Abdollah, P.H. A study of effect of vanadium on microstructure and mechanical properties of as-cast and austempered ductile iron. Phys. Met. Metallogr. 2019, 120, 441-446. [CrossRef]

45. Ramada, M.; Nofal, A.A.; Elmahalawi, I.; Abdel, K.R. Influence of graphite nodularity on microstructure and processing window of $1.5 \%$ Ni-0.3\% Mo austempered cast iron. Mater. Sci. Eng. A 2006, 435-436, 564-572. 
46. Likhite, A.; Parhad, P.; Peshwe, D.R.; Pathak, S.U. Effect of Austenitization Temperature on Wear Behavior of Carbidic Austempered Ductile Iron (CADI). Int. Sch. Sci. Res. Innov. 2014, 8, 510-512.

47. Panneerselvam, P.; Martis, C.J.; Putatunda, S.K.; Boileau, J. An investigation on the stability of austenite in austempered ductile cast iron (ADI). Mater. Sci. Eng. A 2015, 626, 237-246. [CrossRef]

48. Sun, Y.; Hu, S.; Xiao, Z.; You, S.; Zhao, J.; Lv, Y. Effects of nickel on low-temperature impact toughness and corrosion resistance of high-ductility ductile iron. Mater. Des. 2012, 41,37-42. [CrossRef]

49. Nofal, A.A.; Ramadan, M.; Adbel, K.R. Effect of graphite nodularity on structure and properties of austempered cast iron In Proceedings of the 2002 World Conference of ADI AFS Publication, Louisville, KN, USA, 26-27 September 2002; pp. 15-28.

50. Da Silva, A.J.S.T.; Goldenstein, H.; Guesser, W.L.; De Campos, M.F. Quenching and partitioning heat treatment in ductile cast irons. Mater. Res. 2014, 17, 115-1123. [CrossRef]

51. Zhou, W.S.; Zhou, Q.D. Lubricated sliding and rolling wear of austempered ductile iron. Wear 1993, 162-164, 696-702. [CrossRef]

52. Sellamuthu, P.; Harris Samuel, D.G.; Dinakaran, D.; Premkumar, V.P.; Li, Z.; Seetharaman, S. Austempered ductile iron (ADI): Influence of austempering temperature on microstructure, mechanical and wear properties and energy consumption. Metals 2018, 8, 53. [CrossRef]

53. Yang, Y.; Rosochowski, A.; Wang, X.; Jiang, Y. Mechanism of "black line" formation in chilled cast iron camshafts. J. Mater. Process. Technol. 2004, 145, 264-267. [CrossRef] 